\title{
VIII. Lithuanian Courts in Dialogue on International Law
}

Elżbieta Kuzborska*

\section{Introduction}

On 11 March 1990 Lithuania regained its independence. The Act on the Re-Establishment of the State of Lithuania immediately declared the need to 'stay the course' for democracy, human rights protection, and the rule of law. After 50 years of Soviet occupation, the Lithuanian state faced the challenge of a complete change of its political system, the form of the government, and the judicial system. The entirety of its case law, not to mention legal regulations, had to be altered accordingly. Additionally, the European Convention on Human Rights and Fundamental Freedoms was signed by Lithuania on 14 May 1993, and ratified on 27 April 1995. ${ }^{1}$ From the very onset of its operations in 1993, the Constitutional Court of Lithuania (Constitutional Court) referred to the case law of the courts in Strasbourg (European Court of Human Rights) and Luxembourg (Court of Justice of the European Union) and their fundamental principles of democracy, human rights, civil society, legal certainty, proportionality, and accountable governance.

* Dr iur., Member of Board of the Association of Polish Academics in Lithuania, Member of Association of Polish Lawyers in Lithuania.

1 European Convention on Human Rights as amended by Protocols Nos 11 and 14, supplemented by Protocols Nos. 1, 4, 6, 7, 12 and 13, adopted on 4 November 1950 in Rome. 
The continuous reference to international standards in the case law of Lithuanian courts has become increasingly visible. This is connected to the need to apply European Union law and to observe the ECHR's standards, but is also at the same time linked to a greater awareness by the Lithuanian courts that their jurisprudence is increasingly integrated with the European judicial area. While in the first years of the EU membership the Lithuanian courts rather cautiously, or even 'decoratively', evoked EU regulations, the current conduct is perhaps more 'real', though with a certain degree of 'lightness' in the invocation of relevant EU provisions and in rejecting or accepting the interpretation of international standards put forward by the parties in proceedings. Here to light come other interlocutors in 'judicial dialogue': the parties in proceedings and their legal representatives. The analysis of the case law of the Supreme Court of the Republic of Lithuania, as well as of the Lithuanian Supreme Administrative Court leads to the conclusion that the interlocutors of the judicial dialogue (and especially lawyers) are better and better educated and show more and more understanding of the application of the law and the case law of the CJEU and the ECtHR.

To introduce shortly the Lithuanian judicial system one should recall that Lithuania has 62 specialized and general competence courts. The courts of general competence include: 49 district courts (apylinkiu teismai), 5 regional courts (apygardu teismai), the Lithuanian Court of Appeal (Lietuvos apeliacinis teismas), and the Lithuanian Supreme Court (Lietuvos Aukščiausiasis Teismas). They examine civil and criminal cases, with district courts also examining violations of administrative law. Civil and criminal cases may be heard in the regional courts, the Lithuanian Court of Appeal and the Lithuanian Supreme Court. The specialized courts consist in five regional administrative courts (apygardu administraciniai teismai) and the Lithuanian Supreme Administrative Court (Lietuvos vyriausiasis administracinis teismas). These courts deal with administrative matters. The Constitutional Court (Konstitucinis teismas) deals with the questions of constitutionality of laws.

After the 2004 Lithuania's accession to the EU, these national courts became the 'EU courts', in the sense of executing and applying EU law, and ensuring the effectiveness of the rights and freedoms guarded by the Union. The Lithuanian courts also operate as courts complementary to the Strasbourg court guaranteeing the adequate human rights standards and protection. Moreover, in accordance with the principle of subsidiarity, the Lithuanian national courts are the courts of first instance assessing the country's compliance with international law. Similarly, the national judges are increasingly aware of the consequences of non-application of Strasbourg and Luxembourg standards. For the above reasons, Lithuanian courts in their rulings do refer to the decisions of international courts and tribunals, to international law, and to international standards.

The purpose of the following analysis, among others, is to evaluate the role of Lithuanian courts in protecting and implementing international law standards 
through judicial dialogue, along with the underlying purpose, nature, frequency, and practical challenges, as well as difficulties that this involves. Alongside this exploration, answering the following complementary questions is essential a) whether the Lithuanian courts treat the ECHR as an instrument to ensure the domestic legal system's compliance with international law, and in what form they refer to the international law (do they invoke conventional and other source of international law, or international case law?), b) do Lithuanian courts quote international law in a subsidiary manner, as mentioned earlier, basing their judgments mainly on the provisions of Lithuanian law, and, c) does the reference to international standards merely play a 'decorative' role??

\section{The Legal Basis for Judicial Dialogue in the Domestic Law}

According to Article 135 of the Constitution of the Republic of Lithuania "[i]n implementing its foreign policy, the Republic of Lithuania shall follow the universally recognised principles and norms of international law, shall seek to ensure national security and independence, the welfare of its citizens, and their basic rights and freedoms, and shall contribute to the creation of the international order based on law and justice", while Article 138 of the Constitution states that: "international treaties ratified by the Seimas of the Republic of Lithuania shall be a constituent part of the legal system of the Republic of Lithuania." According to the Law on International Agreements ratified international treaties are applied directly and take precedence over legislation and other domestic legal acts. ${ }^{3}$

The Constitutional Court in its rulings repeatedly affirms the primacy of ratified international treaties, but stresses that they cannot apply to the Constitution:

Faithfulness of the Republic of Lithuania to the universally recognized principles of international law has been declared in the Act of the Supreme Council of Republic of Lithuania on 11 March 1990, and in the Act of the Re-Establishment of the State of Lithuania. This means that compliance with freely accepted international commitments and respect of universally recognized norms of international law (including the principle of pacta sunt servanda) constitutes a part of the legal tradition and a constitutional principle of the restored independent State of Lithuania. [...] It should be emphasized that the Constitutional Court has repeatedly stated that ratified international agreements gain the force of law. This doctrinal principle

2 The author would like to express her gratitude to Dr Jolanta Apolewicz for her assistance in researching Lithuanian case law for this article.

3 Article 11 of the Law on International Treaties VIII-1248 (Lietuvos Respublikos Tarptautiniu sutarčiu jstatymas, 22 June 1999). 
cannot be explained in a way that presumes that the Republic of Lithuania may fail to comply with international agreements when international standards are contrary to the [domestic] legal regulation contained in laws or constitutional provisions. On the contrary, the constitutional principle concerning compliance with accepted international commitments and respect of universally recognized norms of international law mean that in those cases where national legislative acts (inter alia legislation or constitutional provisions) provide for an approach which contradicts with the content of an international agreement, the international agreement should be applied. ${ }^{4}$

Similarly, the Lithuanian Supreme Administrative Court in its judgments recognized the direct application of the ECHR provisions by Lithuanian courts and public authorities. On the one hand, in case of any conflict between the provisions of the Convention and domestic law, Lithuanian Supreme Administrative Court gives priority to the treaty. On the other hand, the Supreme Court in one of its rulings held that Lithuanian courts are not obliged to apply directly international soft law. ${ }^{5}$

The Constitutional act on membership of the Republic of Lithuania in the European Union sets the primacy of the whole acquis communautaire over national law, except for the Constitution: "[t]he norms of the European Union law shall be a constituent part of the legal system of the Republic of Lithuania. Where it concerns the founding Treaties of the European Union, the norms of the European Union law shall be applied directly, while in the event of collision of the legal norms, they shall have supremacy over the laws and other legal acts of the Republic of Lithuania."

International treaties and agreements approved by the Government but not ratified in the domestic system do not have priority over legislation, but they do take precedence over regulations and can also be applied directly. For example, the Lithuanian Supreme Administrative Court confirmed the precedence of bilateral international agreements over domestic law: "the applicant is a German company, hence the dispute over the tax should be resolved on the basis of the Lithuanian-German agreement on the avoidance of the double taxation of income and capital, which has precedence over national law."

The Law on courts indicates that courts must adhere to the Constitution, legislation, international agreements, regulations, and other Lithuanian legal

4 Translation from Lithuanian - J. Apolewicz, case 17/02-24/02-06/03-22/04 (Constitutional Court, 14 March 2006).

5 Constitutional Court's decision, 17 October 1995.

6 The Constitutional act on membership of the Republic of Lithuania in the European Union (Lietuvos Respublikos Seimas Istatymas IX-2343 (Žin., 2004-07-13); Lietuvos Respublikos Konstitucijos papildymo Konstituciniu aktu "Dèl Lietuvos Respublikos narystès Europos Sajungoje" ir Lietuvos Respublikos Konstitucijos 150 straipsnio papildymo įstatymas), Article 2.

7 Translation from Lithuanian - J. Apolewicz, case 3K-3-357/2014 (Lithuanian Supreme Court, 20 June 2014). 
acts currently in force that are not contrary to legislation. The courts are obliged to follow the rulings of the Constitutional Court, take into account the judgments of the Supreme Court, as well as the rulings of the Lithuanian Supreme Administrative Court. The courts must apply EU legal standards. They must adhere to the judicial rulings of EU courts, and decisions in preliminary rulings. In turn, the Code of Administrative Proceedings provides that courts cannot apply legislation, which would be contrary to the Constitution; when applying the standards of EU law, the court must be guided by the judicial decisions of EU institutions and preliminary rulings. On the other hand, Article 780 of the Code of Civil Procedure states that in civil proceedings involving foreign parties the provisions of the Code are applied if an international agreement, to which Lithuania is a party, do not provide for a different regulation of the matter at issue.

Therefore, in Lithuanian law there is a strong basis for the direct application of international law and the principle of the supremacy of international law, though not when it comes to the Constitution. Although the law does not refer to the consideration of the judgments of foreign courts, it is undeniable that their use (especially the judgements of European national courts) in order to support a national position is customarily accepted in the European cultural and legal space. An almost complete absence of the reference to the foreign jurisprudence is, however, noticeable in the rulings of the Constitutional Court, the Lithuanian Supreme Administrative Court and the Supreme Court, likely due to the non-existence of such tradition in Lithuania in this respect. When it comes to the practical and technical side of preparing the texts of content decisions and judgements, it is important to emphasize that the courts 'informally' refer to the decisions and judgements of foreign courts (including especially Polish and German cases due to the large convergence of legal regulations) in similar cases. There is evidence of 'indirect' use of case law of foreign countries by Lithuanian courts in the Lithuanian Supreme Administrative Court Bulletin, which contains a review of the case law of foreign courts and the Supreme Administrative Courts.

\section{General Considerations Concerning Judicial Dialogue in Lithuania}

It should be emphasized that the Lithuanian Supreme Administrative Court and the Supreme Court are the most active courts in terms of judicial dialogue in Lithuania. These courts, compared to the Constitutional Court and common courts, will more often refer to international law and the practice of international 
tribunals. It is thought common courts rarely invoke international standards because of their heavy workload, explaining in principle why only the Lithuanian Supreme Administrative Court and Supreme Court have enough time and sufficient human resources for the wider use of judicial dialogue.

This part of the study aims to provide an overview of the general trends concerning the references by Lithuanian courts of international law and enumerate the particular sources of law Lithuanian courts raise in their judgements. Given more recent trends, it should be stated that the Lithuanian Supreme Administrative Court and Supreme Court invoke international law in about 6 to $10 \%$ of their judgments. ${ }^{8}$ In the vast majority, these situations involve EU law, the standards of the European Convention of Human Rights and Fundamental Freedoms (ECHR), and the case law of the European Court of Human Rights (ECtHR). For their part, on average Lithuanian common courts refer to Convention or EU standards in only a few dozen cases a year. Bearing in mind that a district court on average considers 7700 cases every year and a regional court $6900,{ }^{9}$ domestic justifications that include international law covers only around 1 to $2 \%$.

There exists no widespread tradition of referring to international customary law in Lithuanian case law, unless international law or jurisprudence directly appeals to them. For example, the Lithuanian Supreme Administrative Court stated: "One of the universally recognized principle of international law is the principle of sovereign equality. It has been expressed in Article 2 of the Charter of the United Nations, Article 23 of the Vienna Convention on Diplomatic Relations." ${ }^{10}$

An important initiative of the Lithuanian Supreme Administrative Court in the context of uniformity in the practice of common courts in interpreting and using international standards is the already mentioned publication Lithuanian Supreme Administrative Court Bulletin (lit. LVAT biuletenis), which is published twice a year and addressed to all Lithuanian judges and interested institutions. ${ }^{11}$ It discusses the most important Lithuanian Supreme Administrative Court judgments, as well as provides a review of the case law of the tribunals and of the supreme admin-

8 For example, in 2014 Lithuanian Supreme Administrative Court issued 3545 judgments and 171 decisions, of which in 203 judgments and 10 decisions international sources of law were invoked. The vast majority of these were European Convention on Human Rights and the jurisprudence of the European Court of Human Rights (182 judgments and 5 decisions). For comparison, in 2011 Lithuanian Supreme Administrative Court in 196 cases referred to the EU law, and in 308 to the ECHR standards.

In turn, the Lithuanian Supreme Court in 2014 issued 1224 rulings, of which in 140 invoked the international sources - mostly the ECHR, the United Nations Convention on the Recognition and Enforcement of Foreign Arbitral Awards (1958), the Convention on the law applicable to traffic accidents (1971), in several cases to the International Convention on the Rights of the Child, in 10 cases to the Geneva Convention on the Contract for the International Carriage of Goods by Road (1956).

9 Transparency International, Vilnius Branch, <http://atvirasteismas.lt/> (access: 1 July 2016).

10 Case A7-335/2003 (Lithuanian Supreme Administrative Court, 24 June 2003).

11 Bulletin costs around 14 euro. 
istrative court of foreign countries. The review of this publication's recent issues leads to the conclusion that it contains numerous references to EU law and practice of the CJEU, and recalls the standards of the ECHR and its additional protocols, as well as the case law of the ECtHR. The Lithuanian Supreme Administrative Court publication also brings forth examples of the interpretation of domestic law and the rules of law (such as res judicata, non bis in idem, etc.) in the light of international standards. A similar task in dissemination of the knowledge concerning international standards and uniformisation of judicial practices in this respect can be found in the Supreme Court's newsletter Judicial Practice (lit. Teismu prakti$\mathrm{ka}),{ }^{12}$ which, among others, includes an overviews of ECtHR judgments.

Returning to an overview of judicial dialogue in the light of particular international treaties, the Lithuanian Supreme Administrative Court in recent judgments has repeatedly referred to the Convention on Access to Information, Public Participation in Decision-making and Access to Justice in Environmental Matters (the Aarhus Convention). ${ }^{13}$ Basing itself on its provisions, the Lithuanian Supreme Administrative Court has on several occasions described the definition of a 'person concerned' in the context of the protection of the public interest by a non-governmental organization. It has done the same for the definition of 'public interest': "For the purposes of the Aarhus Convention interested non-governmental organization should assist in solving environmental problems, promote environmental protection and meet the requirements determined by national law." ${ }^{14}$

Recently the Lithuanian Supreme Administrative Court, as well as the Supreme Court on a few occasions, have referred to the UNCITRAL Convention on the Recognition and Enforcement of Foreign Arbitral Awards of 1958, ${ }^{15}$ the Hague Convention on the Law Applicable to Traffic Accidents of $1971,{ }^{16}$ the Protocol to the Madrid Convention on Registration of Marks International of $1989,{ }^{17}$ and the Principles of International Commercial Contracts. Both courts directly applied provisions of these conventions. ${ }^{18}$

In cases concerning the protection of children's rights, the Lithuanian Supreme Administrative Court $^{19}$ usually recalls the provisions ECHR, but also

12 The topics discussed in recent issues of the bulletin in the context of international standards: children's rights, recognition of the judgements of arbitration courts, tenders, the right to a fair trail.

13 Adopted on 25 June 1998 in Aarhus.

14 If it is not indicated otherwise, translation from Lithuanian is made by the Author. Lithuanian Supreme Administrative Court's cases: A520-211/2013 (23 September 2013); A-146-342-14 (10 April 2014).

15 Adopted on 10 June 1958 in New York. In 2014 the Convention was invoked for 3 times.

16 Adopted on 4 May 1971 in the Hague.

17 Adopted on 27 June 1989 in Madrid.

18 For example Lithuanian Supreme Court's cases: 3 K-3-363/2014 (27 June 2014); 3 K-7-326/2013 (10 October 2013).

19 On average, every year there are several cases concerning rights of the child. 
refers to the UN Convention on the Rights of the Child, ${ }^{20}$ the Council of Europe's Convention on the Protection of Children against Sexual Exploitation and Sexual Abuse, ${ }^{21}$ and the European Convention on the Legal Status of Children Born out of Wedlock ${ }^{22}$.

As for quoting international standards in criminal cases, the Supreme Court, in addition to the Strasbourg court's standards, applies, among others, the provisions and interpretation of the Council of Europe's Criminal Law Convention on Corruption, ${ }^{23}$ as well as provisions of the Single Convention on Narcotic Drugs. ${ }^{24}$

The Lithuanian Supreme Administrative Court and Supreme Court will on average at least a couple of times every year ${ }^{25}$ invoke the Geneva Convention on the Contract for the International Carriage of Goods by Road (CMR Convention). ${ }^{26}$ In 2014, the Supreme Court recalled in four cases the interpretation of Convention's Article 29(1) stating, for instance, that:

In accordance with the case law of the Supreme Court of Lithuania, the application of Article 29(1) of the CMR Convention, a carrier's grave carelessness, taking into account the specific circumstances of the case, may be compared to deliberate actions and constitute the basis for carrier's full responsibility for the loss of goods. An example of this kind of deliberate misconduct might be breaking red lights, drink driving, violation of the work-rest regime and others. The doctrine agrees that the standard set out in Article 29(1) in case of deliberate damage or carrier-inflicted damage, which under national law is comparable with deliberate actions, is determined according to the provisions of national law and differs in particular countries. ${ }^{27}$

In other cases, the Supreme Court directly referred to the provisions of the Convention, e.g. in determining the meaning of the transport documents for the effectiveness of the contract of carriage $e^{28}$ or in determining the carrier's liability. ${ }^{29}$

When ruling in matters of granting or refusing to grant a refugee status by the Department of Migration within the Ministry of Internal Affairs, the Lithuanian Supreme Administrative Court invoked the provisions of the UN Convention

20 Adopted by General Assembly resolution 44/25 of 20 November 1989.

21 Adopted on 25 October 2007 in Lanzarote.

22 Adopted on 15 October 1975 in Strasbourg.

23 Adopted on 27 January 1999 in Strasbourg. See: case 2 K-368/2014 (Lithuanian Supreme Court, 4 November 2014).

24 Adopted on 30 March 1961 in New York. See: case 2 K-425/2014 (Lithuanian Supreme Court, 21 October 2014). In 2014 Lithuanian Supreme Court issued 10 cases of this kind, in 2015 Lithuanian Supreme Court - 8 cases and Lithuanian Supreme Administrative Court 3 cases.

26 Adopted on 19 May 1956 in Geneva.

27 Case 3 K-3-219/2014 (Lithuanian Supreme Court, 16 April 2014).

28 Case 2 K-388-507/2015 (Lithuanian Supreme Court, 22 September 2015).

29 Case 3 K-3-593-687/2015 (Lithuanian Supreme Court, 6 November 2015). 
relating to the Status of Refugees, ${ }^{30}$ as well as the practice of the ECtHR in assessing the merits of the application and the context of the real risks for an individual in case of deportation (see: Article 3 ECHR on the expulsion or extradition with exposure to torture, inhuman or degrading treatment or punishment). ${ }^{31}$

In cases involving discrimination on grounds of gender and disability in relation to labour legislation, the Supreme Court quoted provisions of the Convention on the Elimination of All Forms of Discrimination against Women ${ }^{32}$ and the Convention on the Rights of Persons with Disabilities, ${ }^{33}$ among others, especially with reference to the burden of proof and the concept of discrimination based on disability, which "includes any form of discrimination, including denial of appropriate adjustment of working conditions [for the disabled worker - E.K.] (e.g. in determining an appropriate model of working time, in allocating of responsibilities, and in ensuring the integration in the workplace)." ${ }^{4}$

Lithuanian courts refer also to other treaties, such as the European Convention on the Transfer of Sentenced Persons of $1983^{35}$ and the Additional Protocol to this Convention of 1997, as well as Convention on the Control and Marking of Articles of Precious Metals. ${ }^{36}$

With regard to bilateral agreements, the Lithuanian Supreme Administrative Court in a 2014 judgment referred to the Lithuanian-German Intergovernmental Agreement on cooperation in the sphere of culture of 21 July $1993^{37}$ and the application of its Article 16:

The parties are unanimous on the fact that lost or illegally exported cultural works within their territory will be returned to their rightful owner or his successors. [...] Article 16 does not specify the time of disappearance or illegal export of cultural works. This means that it cannot be interpreted in a way that gives Parties the right to limit under their national law the range of cultural works, depending on the time of their disappearance or export. ${ }^{38}$

In another judgment the Lithuanian Supreme Administrative Court invoked the Lithuanian-German Agreement on the avoidance of double taxation. ${ }^{39}$

30 Adopted on 28 July 1951 in Geneva.

31 Lithuanian Supreme Administrative Court every year examines several cases of this kind.

32 Adopted on 18 December 1979 in New York.

33 Adopted on 13 December 2006 in New York.

34 Case 3 K-3-199/2014 (Lithuanian Supreme Court, 11 April 2014).

35 Adopted on 21 March 1983 in Strasbourg.

36 Adopted on 15 November 1972 in Vienna.

See: J. Apolevič, E. Leonaitè, Republic of Lithuania Materials on International Law 2014 (Brill Nijhoff, Boston 2016) 442.

371993 m. liepos 21 d. Lietuvos Respublikos Vyriausybès ir Vokietijos Federacinės Respublikos Vyriausybès sutartis dèl bendradarbiavimo kultūros srityje.

38 Case 3 K-3-357/2014 (Lithuanian Supreme Court, 20 June 2014).

39 Case A 438-2713/2011 (Lithuanian Supreme Administrative Court, 28 November 2011). 
The references to soft law, including the recommendations and resolutions of the Council of Europe, aim at strengthening the arguments and reasoning of decisions and at helping in interpreting the provisions of national law. For example, the Lithuanian Supreme Administrative Court in its judgment of 13 July $2012^{40}$ interpreted the norms of the Code of Administrative Procedure regarding the conditions for the application of provisional measures in the light of the Recommendation of the Committee of Ministers of the Council of Europe No. R (89)8 on Provisional Court Protection in Administrative Matters.

The Supreme Court in its judgments often refers to the resolutions of the Parliamentary Assembly of the Council of Europe. For example, in the judgment of 13 June 2014 when examining a cassation appeal, the Supreme Court invoked the Resolution on the Ethics of Journalism, stating that:

resolutions adopted by the Parliamentary Assembly of the Council of Europe have a recommendatory rather than binding force (Articles 22-23 of the Statute of the Council of Europe). By means of its resolution (No. I-1046) of 26 September 1995, the Seimas of the Republic of Lithuania expressed its approval regarding the resolution in question and its recommendation that concrete persons (journalists and employees of the press and other mass communication media, officials of state and municipal institutions) should observe the main ethical principles set out in the resolution. [...] [T] he panel of judges holds that the arguments set out in the cassation appeal regarding the failure of the courts to pay regard to the requirements set in Resolution No. 1003 (1993) of the Parliamentary Assembly of the Council of Europe on the ethics of journalism are unfounded. ${ }^{41}$

It is interesting, however, that in its ruling of 15 May 1998 the Senate of Judges of the Supreme Court of Lithuania noted the recommendatory character of the mentioned resolution but stated that its principles should be observed by journalists and employees of the mass communication media, as well as by state and municipal officials. ${ }^{42}$

\section{Domestic Measures for International Law Infringements}

As far as the effect and the execution of an international judgment in a particular case is concerned, Article 456 of the Code of Criminal Procedure provides that a criminal case can be revised after the UN Human Rights Committee

40 Case AS146-380/2012 (Lithuanian Supreme Administrative Court, 13 July 2012).

41 Case 3 K-3-322/2014 (Lithuanian Supreme Court, 13 June 2014).

42 Decision 1 (Lithuanian Supreme Court Senate, 15 May 1998). 
considers that the conviction was in breach of the ICCPR or its additional protocols, or if the ECtHR acknowledges that the conviction was in breach of the ECHR or its additional protocols, if the nature and gravity of infringements raise serious doubts concerning the legitimacy of a conviction and a violation can be remedied only by reopening the case. ${ }^{43}$ An ECtHR judgment can be also a basis for the revision of civil (Art. 366 Code of Civil Procedure) ${ }^{44}$ and administrative proceedings (Art. 153 Code of Administrative Procedure). ${ }^{45}$

In 2014, in two cases, the Supreme Administrative Court of Lithuania dealt with the impact of decisions adopted by international dispute resolution bodies on the administrative proceedings conducted by the Supreme Court of Lithuania. Both of the cases concerned Rolandas Paksas's disqualification from holding parliamentary office following his removal from the office of the President of the Republic of Lithuania through impeachment proceedings for a gross violation of the Constitution and a breach of the constitutional oath. The Constitutional Court also commented on the case. ${ }^{46}$

The Lithuanian Supreme Administrative Court stated:

The reasoning provided by the European Court of Human Rights and its judgment lead to the conclusion that, by its judgment of 6 January 2011, the European Court of Human Rights did not impose on Lithuania any obligations in relation to the possibility for Rolandas Paksas, the applicant, to participate in elections of the President of the Republic of Lithuania; thus, there is no ground for stating that, at the present moment, the judgment of the European Court of Human Rights gives rise to the international obligation for the Republic of Lithuania to amend the national legislation in relation to presidential elections. [...] Lithuania is under the obligation to execute the judgment of the European Court of Human Rights; however, this can be implemented only by means of amending the Constitution of the Republic of Lithuania, as it was held by the Constitutional Court of the Republic of Lithuania in its special announcement "On the Implementation of the Judgment of the European Court of Human Rights of 6 January 2011" of 10 January 2011, as well as in its ruling of 5 September $2012,{ }^{47}$ where the Constitutional Court held that the sole means of removing the aforesaid incompatibility of the provisions of Article 3 of Protocol No. 1 of the Convention with the Constitution is the adoption of the respective amendment(s) to the Constitution. ${ }^{48}$

43 Law on courts I-480, Art. 456 (LR teismu istatymas, 31 May 1994).

44 Law on civil proceedings IX-743 (LR civilinio proceso kodekso patvirtinimo, jsigaliojimo ir igyvendinimo istatymas, 28 February 2002).

45 Law on Administrative Proceedings VIII-1029 (LR administracinių bylų teisenos įstatymas, 14 January 1999); see: case P-756-46-14 (Lithuanian Supreme Administrative Court, 28 May 2014).

46 See the contribution by I. Skomerska-Muchowska in this volume.

47 Special statement of the Lithuanian Constitutional Court (Lietuvos Respublikos Konstitucinio Teismo specialusis pareiškimas "Dèl Europos Žmogaus teisių teismo $2001 \mathrm{~m}$. sausio 6 d. sprendimo igyvendinimo", Lietuvos Respublikos Konstitucinio Teismo 2012 m. rugsejjo 5 d. nutarimas, 10 January 2011).

48 Case R-525-8-14 (Lithuanian Supreme Administrative Court, 6 March 2014). 
In the subsequent case concerning Rolandas Paksas, which was issued after the decision of the Human Rights Committee, the Supreme Administrative Court of Lithuania indicated:

The applicant points to the Views of the Human Rights Committee of the United Nations, adopted on 25 March 2014, concerning Communication No. 2155/2012 Paksas v Lithuania as a new circumstance, which became known to the applicant on 9 April 2014. In the said views, the Human Rights Committee of the United Nations noted that "the lifelong disqualifications imposed on the author lacked the necessary foreseeability and objectivity and thus amount to an unreasonable restriction under Article 25(b) and (c) of the Covenant [International Covenant on Civil and Political Rights], and that the author's rights under these provisions have been violated." The panel of judges holds that the circumstance indicated by the applicant does not satisfy the grounds for reopening proceedings, as provided for in Item 2 of Paragraph 2 of Article 153 of the Law on the Proceedings of Administrative Cases, since the aforementioned statements should be considered not as a new circumstance but as a new assessment of the facts that existed at the time of the consideration of the case, given by the Human Rights Committee of the United Nations already after the decision in the administrative case had been adopted. ${ }^{49}$

The ECtHR's judgment in Cudak v Lithuania ${ }^{50}$ was also the basis for the reopening of proceedings. The case is interesting and requires a discussion broader than it is possible here since it clearly shows the limitations of state immunity. What's important, Lithuania is not a party to UN Convention on Jurisdictional Immunities of States and Their Property, ${ }^{51}$ nor European Convention on State Immunity. ${ }^{52}$ The mentioned decision of the ECtHR has become an expression of the evolution of standards concerning immunity from legal proceedings, moving away from the restrictive theory of immunity, which in an absolute way was supposed to protect a State against any claims before the courts of other countries. The Grand Chamber of the Court found a violation of the applicant's right to access to a court (Article 6(1) ECHR) due to the refusal of Lithuanian courts to proceed with a lawsuit against the Embassy of Poland in Vilnius after the Ministry of Foreign Affairs of Poland invoked immunity from jurisdiction, concluding that the duties entrusted to the applicant in the Embassy of Poland had "facilitated, to a certain degree, the exercise by the Republic of Poland of its sovereign functions." ${ }^{53}$ In its

49 Case P-492-71-14 (Lithuanian Supreme Administrative Court, 30 April 2014).

Cudak v Lithuania, App. no. 15869/02 (ECtHR, 23 March 2010).

Adopted on 2 December 2004 in New York.

Adopted on 16 May 1972 in Basel.

53 A brief statement of facts: the applicant Alicja Cudak starting from 1.11.1997 was employed at the Polish Embassy in Vilnius as a secretary and switchboard (local staff member, an employment contract governed by the law of Lithuania). In 1999 AC appealed to the Lithuanian Ombudsman of Equal Opportunities claiming she was a victim of sexual harassment from the Polish diplomat. The proceedings before the Ombudsman proved the harassment. 
judgment of 23 March 2010, the ECtHR stated that, although neither Lithuania nor Poland have signed and ratified the European Convention on State Immunity and the Convention on Jurisdictional Immunities of States and Their Property, the provisions of the latter (in particular Article 11 concerning employment contracts) should be treated as a codification of norms of customary international law.

The ECtHR admitted that the measures taken by the State due to the recognition of jurisdictional immunity couldn't disproportionately restrict the right of access to a court (Article 6(1) ECHR). According to the ECtHR, the applicant performing as a secretary did not perform functions closely related to the public authority, she did not have the status of a staff member of the diplomatic or consular corps, and was a citizen of the host country. The Court noted that the Lithuanian Government was unable to explain how the performance of her duties was related to the sovereign interests of the Polish government and the security interests of Poland, so it was assumed that the applicant's employment contract involved only the sphere of acta jure gestionis (acts of a commercial or private-law nature), and no sphere of acta jure imperii (acts of sovereign authority). The ECtHR stated that Poland's reference to immunity from the jurisdiction does not give the Lithuanian courts grounds to reject the claims concerning the employment contracts of the local staff of the Polish Embassy, since the principle of state immunity cannot be applied in cases of labour law involving the citizens of the host country working in foreign diplomatic missions. In conclusion, the Court stated that by upholding an objection based on State immunity and by declining jurisdiction to hear the applicant's claim, the Lithuanian courts, in failing to preserve a reasonable relationship of proportionality, overstepped their margin of appreciation and thus impaired the very essence of the applicant's right to access to a court. It was stressed that each case requires individual assessment in the context of the principle of proportionality. ${ }^{54}$ It should be assessed that the judgment has revaluated and confronted the principle of absolute state immunity in international law.

Due to this ECtHR ruling, the Lithuanian Supreme Court on 7 October 2010 set aside the previous ruling in Cudak and ordered a retrial of the lawsuit concerning unlawful dismissal and monetary compensation. The case was examined in two instances. Domestic courts did not refer to or analyse the ECtHR's judgement involved, but focused mainly on the merits of the case and the provisions of Lithuanian labour law. ${ }^{55}$

On 2.12.1999 AC was informed of her dismissal from work because of unauthorised absences on 22-29.11.1999. After making a complaint before Lithuanian against the employer - Embassy of Poland, Ministry of Foreign Affairs of Poland invoked immunity against jurisdiction. The court dismissed the claim, the court of appeal uphold it, Supreme Court found no violation as well.

55 The court of the first instance dismissed the claim. After A. Cudak appealed the court partially recognized her claim - found her dismissal to be illegal and awarded her the compensation of 50,000 litas (about 60,000 PLN, while AC demanded 500,000 litas), but did not reinstate 
It should be mentioned that prior to Cudak case, the Lithuanian courts in a less systematic manner, on a case-by-case basis, examined two more cases concerning State immunity. On 5 January 1998 the Supreme Court issued a decision in the case of Stukonis $v$ United States embassy, regarding an action for unlawful dismissal against the United States embassy in Vilnius. It found, inter alia, as follows: "State immunity does not mean immunity from institution of civil proceedings, but immunity from jurisdiction of courts. The Constitution establishes the right to apply to a court (Article 30) [...]. However, the ability of a court to defend the rights of a claimant, where the defendant is a foreign State, will depend on whether that foreign State requests the application of the State immunity doctrine [...]. In order to determine whether or not the dispute should give rise to immunity $[\ldots]$ it is necessary to determine the nature of the legal relations between the parties [...]."56

On 6 April 2007 the Supreme Court delivered a judgment in a case S.N. $v$ the embassy of the Kingdom of Sweden. It found that "despite the fact that the Kingdom of Sweden had not enacted any legislation on State immunity, it could nevertheless be seen from the case-law of the domestic courts that Sweden recognised the doctrine of restrictive State immunity." In that case it was considered that the provisions of the United Nations Convention on Jurisdictional Immunities of States and their Property, adopted on 2 December 2004, could be taken into account, even though they were not binding, since they reflected a certain trend in international law in matters of State immunity. The Supreme Court further observed that the case law of the courts of both States, Lithuania and Sweden, based on common practice in international relations, confirmed that they had been adhering to a restrictive approach to State immunity, whereby a State could not claim immunity from jurisdiction if the dispute was of a private law nature. In such cases Sweden could not therefore object to the case being heard by the Lithuanian courts. ${ }^{57}$

Summing up, in cases concerning State immunity Lithuanian courts invoked international customary law, rejecting a restrictive approach to State immunity.

Another issue relevant for our discussion is the enforcement of international judgments, which would require the introduction of changes in domestic laws. Without a doubt, decisions of the ECtHR in cases against Lithuania, which oblige the state to change legislation, and their application, are of particular importance. On the one hand, some are executed efficiently. These are, for example, cases concerning conditions in prisons result in the amendment of the domestic law. On the other hand, no appropriate legislative changes were taken to comply with the 2007 judgment L. $v$ Lithuania to create the legal possibility of gender change surgery and enable subsequent changes in civil registry. ${ }^{58}$

her, see: case 2-1212-553/2011 (Vilnius district court, judgment, 13 May 2011); case 2-1212553/2011 (Vilnius Court of Appeal, judgment, 11 November 2011).

56 See: Cudak v Lithuania, App. no. 15869/02 (ECtHR, 23 March 2010), para. 21.

57 See: ibidem, para. 23.

58 See: case A858-1452/2010 (Lithuanian Supreme Administrative Court, 29 November 2010). 


\section{The Application of EU Law}

The following considerations refer to the application of EU law by national courts and its evolution since, as it was stated at the beginning of this contribution, Lithuanian courts are considered to be also the EU courts.

Before its accession to the EU, Lithuania was obliged to adapt national laws to EU regulations. In 2003, amendments to the Law on the Judiciary, Code of Administrative Offences, Code of Civil Procedure, and Code of Penal Procedure were adopted. The changes were aimed, first, at enabling the courts to apply the EU law, and second, at creating the basis to issue a preliminary ruling in case of doubt as to the existing regulations or interpretation of EU law: "The court, when considering the case, applies standards of EU law as well as the decisions of the EU judicial institutions EU, the preliminary rulings concerning the application of the existing EU law and its interpretation." ${ }^{59}$ Article 3(5) of the Code of Civil Procedure obliged courts to apply standards of EU law and to take into consideration the decisions of the EU judicial institutions and preliminary rulings concerning the application and interpretation of EU law.

These amendments entered into force on the date of Lithuania's accession to the EU, but it must be remembered that the primary legislation of the EU obliged Member States to comply and apply the EU law. In addition, the Constitutional Act on Membership of the Republic of Lithuania in the European Union adopted after the country's accession to the EU, affirms that EU law is an integral part of national law and should be applied directly, and established EU law's precedence over national laws.

The Supreme Court was the first court in Lithuania to apply EU law, even before the country's accession to the EU. When answering the question as to the basis and the purpose of the Supreme Court's reliance on acquis communautaire before Lithuania's accession to the EU - it must be noted that the Court did this for the pre-accession adjustment of national law to EU standards. In its judgment in the civil case of UAB Sirowa $v$ Office of Competition in 1998, the Supreme Court briefly analysed and explained domestic regulations in the context of EU law, noting only that some of the national law provisions conform to the provisions of EU directives, without offering an analysis of the concepts and principles of EU acts, nor specifying the place of EU law in the Lithuanian law system. ${ }^{60}$

Another example is the judgment in a civil case from 25 January 2000, UAB "Birštono Mineraliniai vandenys ir Ko" v UAB "Naujieji Birštono Mineraliniai

59 Law on Civil Proceedings 36-1340 (Lietuvos Respublikos civilinio proceso kodekso 3 str. 5 dalis, Valstybès Žinios, 2002).

60 Sirowa v Konkurencijos Taryba 3 K-53/1998 (Lithuanian Supreme Court, 14 September 1998). 
vandenys", ${ }^{61}$ in which the Court, explaining the concept of 'the place of origin', used the provisions of European Commission Regulation (EEC) of 14 July 1992 No. 2081/92 on the protection of geographical indications and designations of origin for agricultural products and foodstuffs. The Court noted "the place of origin of goods firstly is related to the geographical origin. Despite the fact that Lithuanian law on goods and trademarks does not contain the definition of geographical indications or geographical origin, however, the explanation of such definitions in relation to trademarks is in international documents." ${ }^{62}$ As one can observe, the Court did avoid naming in a direct manner an EU regulation, nor did it specify on what grounds the EU law should be applied in a Lithuanian case. Furthermore, the Court did not analyse the binding force of the EU regulation in the Lithuanian legal system. ${ }^{63}$

The first time the Supreme Court referred directly to EU law was in the judgment of 17 May 2000 in the civil case of Aheuser-Busch Incorporated $v$ Budejovichy Budavar $N$ and others. ${ }^{64}$ The Court noted that "taking into account the fact that contemporary intellectual property law is a result of long-standing unification and harmonization of law [...] and taking into account the aspirations of Lithuania to the EU integration and the consequent need to adapt national law with EU law, Article 3(4) of the Lithuanian Law on goods and trademarks should be interpreted and applied in the context of international law and EU law." ${ }^{65}$ The Supreme Court linked the obligation to apply EU law with the obligation of Lithuania on the pre-accession harmonization of national law. ${ }^{66}$

It is worth mentioning that at that time Lithuania only had the basic domestic intellectual property laws. The Supreme Court therefore correctly referred to the EU solutions in this respect in order to properly resolve the dispute on the basis of national legislation. In the same vein, the Supreme Court ruled in a judgment of 15 December 2003 in a civil case, Beecham Group $v$ Kelupas: ${ }^{67}$

taking into account the specific nature of cases in this area [the protection of intellectual property - E.K.], which Lithuania has just formed, and that there is no significant Lithuanian

61 Birštono mineraliniai vandenys ir Ko 3 K-3-25/2000 (Lithuanian Supreme Court, 25 January 2000).

62 Ibidem.

63 See: E. Strazdaite, Europos Sajungos teises taikymas Lietuvos Respublikos teismuose (Vilniaus universitetas 2007) 17.

64 Aheuser-Busch Incorporated v Budejovichy Budavar N ir kt. 3 K-3-554/2000 (Lithuanian Supreme Court, 17 May 2000).

65 See per analogiam: Smirnova v UDV North America 3 K-3-167/2003 (Lithuanian Supreme Court, 7 January 2003).

66 It should be emphasized that at the same time other courts of the countries-candidates for EU membership ruled in the same spirit. For example, The Constitutional Court of Poland in 1997 pointed out that the obligation to ensure compliance of national legislation with Community law results from the Association Agreement. See: E. Strazdaite, op. cit., 17.

67 Beecham Group v Kelupas 3 K-3-1103/2003 (Lithuanian Supreme Court, 15 December 2003). 
courts practice in this respect, the correct interpretation and application of this law is of particular importance. [...] A significant fact is the high level of harmonization of trademark law at EU level, their impact on domestic law and courts practice, it is also important that starting from 1 May 2004 Lithuania will be bound by the Community trade mark law and, obviously, disputes concerning the national regulations will arise which the Lithuanian courts will be obliged to settle.

In other matters concerning the protection of intellectual property rights, the Supreme Court referred to the practice of the CJEU: "[ $t]$ he direction of the practice of the European Court of Justice shows that the average consumer is well informed, observant and circumspect." ${ }^{\prime 6}$

It should be noted that issues concerning the protection of intellectual property were the exception when it comes to the pre-accession direct acceptance of or reference to a specified EU legal standard by Lithuanian courts. During the same period in other judgments, the Supreme Court only took into account the existence of 'international instruments' in a broad sense of international law, without specific references to EU legislation. As some authors pointed out, this kind of disregard for EU law at that time resulted from an abstract understanding of the concept of the EU as an international organization. ${ }^{69}$

In general, the application of EU law immediately after the 2004 Lithuania's accession to the Union, when the Lithuanian courts were obliged to apply directly the Community law, was not without blemish. For example, in a civil case of 12 May 2004, Lietuvos medicinos darbuotoju profesine sajunga v VŠt Kauno miesto greitosios medicinos pagalbos stotis ${ }^{70}$ the Supreme Court referred to an EU Directive 2002/14/EC establishing a general framework for informing and consulting employees in the European Community cited by the appellant, even though Lithuania had not transposed it into a national law.

In a civil case of 21 March 2005, Julius Meinl International AG v Gustav Paulig $L t d,{ }^{71}$ the Supreme Court found the arguments of the defendant based on the CJEU case law inaccurate:

The defendant's trademark has nothing special (the statement of the defendant, as if the word 'PRESIDENT' has some particular elements has no grounds) and the reference made by

68 Lithuanian Supreme Court's cases: UAB Rasa, UAB Vegoplastas, UAB Druskininkų Rasa $v$ R. Degutienés imoné Kertupis $3 \mathrm{~K}-3-875 / 2001$ (1 October 2001); Sèkmés sistemos v AB Lietuvos telekomas, UAB Lietuvos telekomo verslo sprendimai 3 K-3-927/2001 (1 October 2001); Distilleerderijen Erven Lucas Bols B.V. v UAB Bennet Distributors 3 K-3-375/2003 (26 March 2003); E. Strazdaite, op. cit., 19.

69 See: E. Strazdaite, op. cit., 19.

70 Lietuvos medicinos darbuotojų profesiné sajunga $v$ VŠl Kauno miesto greitosios medicinos pagalbos stotis 3 K-3-301 (Lithuanian Supreme Court, 12 May 2004).

71 Julius Meinl International AG v Gustav Paulig Ltd 3 K-3-135 (Lithuanian Supreme Court, 21 March 2005). 
the defendant to CJEU rulings in cases Sabel BV v Puma AG, No. C-251/95 and Canon Kabushiki Kaisha v Metro-Goldvyn-Mayer Inc., No. C-39/97, should be considered as groundless, as the cases $[\ldots]$ refer to 'a very clear' specific characteristics of the trademark's element.

Here the Supreme Court very widely invoked the practices of the CJEU in cases concerning the protection of intellectual property. Similarly, in the case of Unilever N.V. $v$ UAB Varta ${ }^{72}$ the Supreme Court rejected the arguments of the defendant, analysing and invoking what was at that time the latest CJEU case law concerning the dispute over the use of identical chemicals' packaging. This indicates at that time a growing understanding of the CJEU case law, and an increasing awareness by the parties in the dispute of the need to invoke the arguments and standards of EU law.

It should be noted that since the end of 2005 the practice of the Supreme Court concerning the application of EU law has become more clear and conscious, and the reasoning in its judgements stronger. In turn, the parties in their arguments have more often raised arguments concerning EU standards (directives, regulations) and practical aspects of the application of the acquis communautaire.

As for the quantitative assessment of the categories of cases in which the Supreme Court usually refers to the law and practice of the EU, unquestionably the first place goes to rulings related to the protection of intellectual property (patents, trademarks),${ }^{73}$ and to the principle of free movement of goods and services. ${ }^{74}$ The Supreme Court in its judgements focuses on a verification of the assessment of judicial practice of the CJEU made by the common courts, ${ }^{75}$ and on a verification of the parties' arguments in this respect and the assessment of national laws in the context of EU standards. ${ }^{76}$ Thus the Supreme Court in a clear and direct way applied EU law in the Nike International Ltd. $v$ UAB Rivona,${ }^{77}$ in particular Council Regulation (EC) No. 1383/2003. ${ }^{78}$ The Court in its judgment held that the rules of national law should be interpreted and applied in a systemic way along with EU standards. It confirmed the direct effect of EU law in national law and stressed that due to Lithuania's membership in the EU, EU law has become a part of national law, hence national laws contrary to it cannot be applied.

72 Unilever N.V. v UAB Varta 3 K-3-150 (Lithuanian Supreme Court, 23 March 2005).

73 See: Strazdaite E., op. cit., 21.

74 See inter alia: Autoplastik v Laverna 3 K-3-477-684/2015 (Lithuanian Supreme Court, 18 September 2015).

75 Sanofi-Synthelobo v Egis Gyogyszergyar RT 3 K-3-202 (Lithuanian Supreme Court, 22 March 2006).

76 Kirkbi A/S (procesinis teisiu perèmèjas - Danijos bendrové Lego Juris A/S) v UAB Legosta 3 K-3-209 (Lithuanian Supreme Court, 27 March 2006).

77 International Ltd. v UAB Rivona 3 K-3-669 (Lithuanian Supreme Court, 20 December 2006).

78 European Council Regulation (EC) No. 1383/2003 of 22 July 2003 concerning customs action against goods suspected of infringing certain intellectual property rights and the measures to be taken against goods found to have infringed such rights. 
As for the other categories of cases in which the Supreme Court refers to the $a c$ quis communautaire and its practical application, proceedings in civil matters must be mentioned. In this context the Supreme Court examined the notion of justice, delivery of notices and subpoenas, collection of evidence, and recognition and enforcement of judgments of EU Member States. In this respect, the Supreme Court usually refers to Council Regulation (EC) No. 44/2001 of 22 December 2000 on jurisdiction and the recognition and enforcement of judgments in civil and commercial matters (Brussels I): ${ }^{79}$ Council Regulation (EC) No. 2201/2003 of 27 November 2003 (Brussels II bis) concerning jurisdiction and the recognition and enforcement of judgments in matrimonial matters and the matters of parental responsibility, European Parliament and Council Regulation (EC) No. 1348/2000 of 29 May 2000 on the service in the Member States of judicial and extrajudicial documents in civil or commercial matters, ${ }^{80}$ Council Regulation (EC) No. 1206/2001 of 28 May 2001 on cooperation between the courts of the Member States in the taking of evidence in civil or commercial matters, and Council Regulation (EC) No. 1346/2000 of 29 May 2000 on insolvency proceedings and others.

In some cases, the Supreme Court clearly shows the shortcomings of common courts when they improperly interpret the practice of the CJEU or apply national law without referring to the principle of the primacy of the EU law. ${ }^{81}$ For example, in matters concerning the protection of a child's rights, the Supreme Court emphasized the primacy of the EU law over the provisions of the Hague Convention on the Civil Aspects of International Child Abduction. ${ }^{82}$ Often, the Supreme Court relies on EU standards in matters relating to the energy sector. ${ }^{83}$

Conversely, a typical example of the Lithuanian Supreme Administrative Court's reference to EU law can be found in its judgment of 2009 No. N575-1387/2009 on administrative violation in the field of wrapping car's windshields with foil to reduce light transmission. First, the Lithuanian Supreme Administrative Court specified its basis for the EU law application, the Constitutional Act "On membership

79 Lithuanian Supreme Court's cases: Ūkio bankas v Commerzbank AG 3 K-3-685-219/2015 (23 December 2015); R. Š. v Brenalan Investments Limited, Grand Go Group Limited i Grand Cru Airlines e3 K-3-406-378/2015 (26 June 2015).

80 See for example: case Lietuvos Respublikos aplinkos ministerijos Aplinkos projektu valdymo agentūra v Dekont International s.r.o. 3 K-3-690/2006 (Lithuanian Supreme Court, 29 December 2006).

81 See for example: Lithuanian Supreme Court's cases: UAB Bleiras v TIMA TRANSPORTS 3 K-3-170 (6 March 2006); Lietuvos Respublikos aplinkos ministerijos Aplinkos projektų valdymo agentūra $\checkmark$ Dekont International s.r.o. 3 K-3-690 (29 December 2006); See for example: Lithuanian Supreme Court's cases: UAB Kauno termofikacijos elektrinè v AB Lietuvos energija (14 May 2012); Kauno termofikacijos elektrinè v Lietuvos energijos gamyba 3 K-3-4-378/2016 (3 February 2016).

82 Adopted on 25 October 1980 in the Hague. See: case M.R. v I.R. 3 K-3-91/2008 (Lithuanian Supreme Court, 7 January 2008).

83 For example: case Kauno termofikacijos elektrine v Lietuvos energijos gamyba 3 K-3-4-378/2016 (Lithuanian Supreme Court, 3 February 2016). 
of the Republic of Lithuania in the European Union", which in Article 2 states that the standards of EU law are part of the Lithuanian legal system, and that if this is due to the European treaties, norms of this law are applied directly and have precedence in the event of a conflict with provisions of national laws. It also quoted the judgement of the Constitutional Court, which explained that these provisions expressis verbis establish the conflict of law rule concerning the primacy of application of EU law in case of conflict with national laws, except for the Constitution. ${ }^{84}$ Next, the Lithuanian Supreme Administrative Court stated:

Therefore national technical requirements for road vehicles cannot be applied in the case of their non-compliance with the standards of EU law, including the Treaty establishing the European Community. [...] Article 28 of the Treaty establishing the European Community specifies that: "Quantitative restrictions on imports and all measures having equivalent effect shall be prohibited between Member States." The Treaty a principle of free movement of goods described as one of the fundamental principles of EU law (CJEU judgment of 12 June 2003 in Eugen Schmidberger and others, case No. C-112/00, para. 51), and Article 28 is applied directly (CJEU judgment March 22, 1977 on Ianelli case, No. C-74/76). According to the practice of the CJEU, quantitative restrictions are any means that fully or partially restrict import or export, and each rule of national law, which directly or indirectly, actually or potentially restricts trade within the Community should be assessed as a measure having equivalent effect to quantitative restrictions (CJEU judgment of 11 July 1974 in Dassonville case, No. C-8/74).

Next, the Lithuanian Supreme Administrative Court cited Article 4(3) of the Act on Proceedings in Administrative Matters, which states that a court in the application of EU law should be guided by the judgments and preliminary rulings of EU judicial institutions:

In considering this matter, the judgment of the CJEU of 10 April 2008 in the EU Commission $v$ Portugal case (No. C-265/06) should be recalled, in which the CJEU ruled on the question whether the absolute ban on covering the front and side windows with a foil that reduces the light transmission is an obstacle to trade colour foil that was legally produced in another country. [...] The CJEU held that the mentioned prohibition is not proportional to the objectives pursued and found that the state, which prohibits wrapping the car's windows with a foil of any colour does not comply with the Articles 28 and 30 of the Treaty establishing the European Community. [...] Although the college of judges notes that establishing a prohibition to wrap the car's windows probably sought to ensure road safety, which, according to the practice of the CJEU, in some circumstances may justify restrictions on the free movement of goods (judgment of the CJEU of 5 October 1994 in Van Schaik case, No. C-55/93, para. 19; judgment of the CJEU of 21 March 2002 in Cura Anlagen case, No. C-451/99, para. 59), but in the present case there is no sufficient basis to justify the restriction. Unification

84 Constitutional Court's decisions (14 March 2006 and 21 December 2006). 
of technical standards for motor vehicles essentially has three objectives to be achieved: road safety, environmental protection, guarantees concerning market purchase and sale of motor vehicles by removing technical limitations when it comes to this kind of trade. The Commission Directive of 30 October 2001 No. 2001/92/EC, which includes requirements for road safety, and provides that the transmission of light in the windscreen and front side windows of cars can be at $75 \%$ and $70 \%$ level must be taken into account. This allows to draw a conclusion on the fact that even seeking to ensure road safety, perhaps it would be sufficient to require compliance with the level of the transmission of light in the windscreen and front side windows [rather than introducing a complete ban - E.K.]. [...] Especially in Lithuania in general one can trade cars that have factory-tinted windscreen and front side windows, if they comply with the necessary light transmission requirement. Therefore, a broad and absolute prohibition concerning wrapping the car's windows with any foil has no justification because of disproportionality in the context of the objectives to be achieved. State institutions, which addressed the court, did not indicate any specific arguments and evidence that could fully justify the restriction on the movement of goods and limited their argumentation to general statements.

Considering the above, the Lithuanian Supreme Administrative Court stated that an absolute prohibition concerning wrapping a car's window with any foil that reduces light transmission in domestic law is contrary to EU law and the principle of the primacy of its legislation. This prohibition was deemed as restricting the free movement of goods, foils, within the Community and was considered equivalent to an unlawful quantitative restriction within the meaning of Article 28 of the Treaty establishing the European Union. ${ }^{85}$

The Lithuanian Supreme Administrative Court in this case assessed in a comprehensive manner EU standards in the context of the free movement of goods, and interpreted EU law in the circumstances of the case, recognizing the contradiction of national rules with EU law.

\section{Implementing Strasbourg's Standards - Review of the Examples of Judicial Dialogue}

The special importance of the European Convention on Human Rights and Fundamental Freedoms in the Lithuanian legal system is expressed in the rulings of the Constitutional Court, as well as the Supreme Court. The Constitutional Court of Lithuania has stated that the human rights contained in the Constitution should be interpreted in the light of the ECHR provisions. It highlighted

85 Case 575-1387-09 (Lithuanian Supreme Administrative Court, 28 December 2009). 
the special significance of the case law of the ECtHR as a tool for the interpretation and application of domestic law. ${ }^{86}$

Moreover, in one of its judgments, the Supreme Court tried to somehow 'soften' the primacy of the Constitution in respect of ratified international agreements, and attempted to reconcile its provisions with the ECHR in the context of the importance and significance of human rights standards:

The Constitution of the Republic of Lithuania and the Convention are aimed at achieving the same objectives of human rights protection at different levels - at the national and international level, respectively. The legal system of the Republic of Lithuania is based on the principle that any law or any other legal act, as well as any international agreements of the Republic of Lithuania (including the Convention), may not be in conflict with the Constitution. The Convention does not directly formulate any requirement (as this would be impossible to implement) that domestic legal norms must literally correspond to the content of the norms of the Convention. [...] A concrete state itself may establish by what the means to ensure the application of the provisions of the Convention. The interpretation of the compatibility (relationship) of the norms of the Constitution and the Convention should be notional and logical, rather than merely literal (word for word). [...] The provisions of the Convention that define human rights and freedoms may be applied along with the provisions of the Constitution, provided they do not contradict the latter [...]. In addition, the Constitutional Court noted that the jurisprudence of the European Court of Human Rights, as a source of interpretation of law, is equally relevant to the interpretation and application of Lithuanian law $[\ldots] .{ }^{87}$

In its case law, the Lithuanian Supreme Administrative Court noted more than once that the nature of the ECHR, as a legal act of international origin, as well as its purpose, the protection of human rights, determines the fact that this Convention is directly applied in the course of court proceedings in the Republic of Lithuania, whereas in the event of a conflict with the national legislation, it has a priority over the national legislation: ${ }^{88}$ " $[\mathrm{t}]$ he principle of direct application of the ECHR means that its provisions can be invoked before the Lithuanian courts, as well as in relations with public administration." 89

Lithuanian courts often treat the provisions of the ECHR as a tool for interpretation of national law. For example: "for the purposes of interpreting the provisions of the Law on Police Activities in a systematic manner and ensuring the effective

86 Constitutional Court's decision (8 May 2000); see case 3 K-3-324/2014 (Lithuanian Supreme Court, 20 June 2014).

87 Constitutional Court's conclusion (24 January 1995); see case 3 K-3-324/2014 (Lithuanian Supreme Court, 20 June 2014).

88 See e.g. case A575-164/2008 (Lithuanian Supreme Administrative Court, 14 April 2008).

89 Lietuvos vyriausiojo administracinio teismo $2014 \mathrm{~m}$. balandžio $9 \mathrm{~d}$. aprobuotas Lietuvos vyriausiojo administracinio teismo praktikos, nagrinejjant bylas dèl bausmių vykdymo ir kardomojo suẻmimo institucijų, istaigų ir pareigūnų veiksmų ir sprendimų viešojo administravimo srityje, apibendrinimas", Administraciné jurisprudencija (2014) 26, pp. 460-564. 
implementation of the obligations of Lithuania under Article 2 of the Convention, and in applying and interpreting the Lithuanian legal provisions governing the responsibility of officials for the use of force, account must be taken of the requirements formulated in the case law of the ECtHR in relation to Article 2 of the Convention."90

\subsection{The Right to a Fair Trial and other Procedural Guarantees}

In approximately 40 to $50 \%$ of its judgments, the Lithuanian Supreme Administrative Court refers to international legislation concerning the standards of the right to a fair trial (Article 6 ECHR), the prohibition of torture, inhuman or degrading treatment or punishment (Article $3 \mathrm{ECHR}$ ) in the context of the conditions in Lithuania prisons, to the excessive length of judicial proceedings, arrests, etc. Most often the complaints concern the overcrowding of prisons or detention cells. In order to avoid further complaints against Lithuania before the ECtHR, Lithuanian courts broadly refer to treaty standards in this regard, usually granting compensation for violations. In such cases the Lithuanian Supreme Administrative Court, in the context ECHR standards, assesses whether prisoners suffered negative experiences, a sense of inferiority, and the necessity of imprisonment within the meaning of Article 3 of the Convention.

For example, in 2014 the Lithuanian Supreme Administrative Court invoked Article 6 ECHR together with the case law of the ECtHR in 9 cases of revision, in 8 cases of judicial assessment of the arguments presented by the parties, ${ }^{91}$ and in 4 cases concerning the right to a fair trial (in the context of ECtHR case law, the Court considered both objective and subjective criteria to determine a judge's impartiality). ${ }^{92}$ In 27 cases, the Lithuanian Supreme Administrative Court decided on procedural questions, for such as the following:

consideration should also be given to the right of the accused person to a hearing within a reasonable time (para. 1 of Article 6 of the Convention, para. 5 of Article 44 of the Code of Criminal Proceedings). In accordance with the case law of the ECtHR and Lithuanian courts, the reasonableness of the length of the proceedings is to be assessed in the light of concrete circumstances of the case and having regard to the criteria formulated by the ECtHR - the complexity of the case as well as the conduct of the applicant and the respective authorities in the course of organising the proceedings; the significance of the proceedings (what was at stake) for the accused person.

90 Case 2 K-P-1/2014 (Lithuanian Supreme Court, 30 January 2014), Teismy praktika (2014) 40402.

91 For example: Lithuanian Supreme Administrative Court's cases: A-146-95-14 (10 February 2014); A-442-707-14 (9 October 2014).

92 For example: case P-492-71-14 (Lithuanian Supreme Administrative Court, 30 April 2014). 
The Lithuanian Supreme Administrative Court in its judgments invokes a standard of Article 4 of Protocol 7 to the ECHR regarding the clarification of the principle of ne bis in idem. ${ }^{93}$

The Supreme Court in 2015 considered the standard of Article 6 ECHR in the context of the excessive length of proceedings invoked in 14 criminal and civil cases. The Supreme Court assessed the legitimacy of the duration of the proceedings taking into account the particular circumstances of the case and the criteria formulated in the ECtHR practice such as the level of complexity of the case, the behaviour of an applicant and state institutions in the organization of the judicial proceedings, the importance of the process for an applicant: ${ }^{94}$

[t] he right to a fair hearing, as consolidated in Article 6 of the Convention for the Protection of Human Rights and Fundamental Freedoms [...], may not be sacrificed to secure speedy proceedings. In accordance with the case law of the European Court of Human Rights, although Article 6 of the Convention requires that court proceedings be expeditious, this article also gives a particular importance to the proper administration of justice (see, for example, Maltzan and Others $v$ Germany (GC), (dec.), No. 71916/01, decision of 2 March 2005, para. 132). Thus, in substance, the judge of a national court, while being the chief executive of the proceedings, decides on the need of concrete procedural measures in order to, first of all, fairly solve the case. ${ }^{95}$

The reference to the ECHR standard is also found in earlier cases:

the appellant relies on the standard of Article 6 ECHR concerning the excessive length of judicial proceedings. [...] The provisions of the Lithuanian Code of Civil Procedure essentially fulfil the obligation of the state articulated in Article 6(1) ECHR with regard to the organization of the judicial system in a way that guarantees that state institutions are doing everything in order to conduct the proceedings without undue delay or interruption (e.g.: Makarenko v Ukraine, No. 43482/02, judgment of 1 February 2007, para. 37). Therefore, the length of civil proceedings, as defined in Article 6(1) ECHR, is not measured by the duration of the proceedings, but by the improper conduct of the process, when the process has been unjustifiably suspended or delayed [...] (see: a contrario Veljkov v Serbia, No. 23087/07, para. 88, 19 April 2011; Wildgruber v Germany, No. 42402/05, para. 61, 21 January 2010). [...] Therefore, the college of judges considers that the court of first instance organized the proceedings in an appropriate manner and notices no possible breach ECHR. ${ }^{96}$

93 Lithuanian SupremeAdministrativeCourt's cases:A-556-1535-14(28October2014);A-444-2727/2012 (9 August 2012); A-520-2823/2012 (17 September 2012); A-662-1579-14 (19 May 2014).

94 Case 3 K-3-302/2014 (Lithuanian Supreme Court, 6 June 2014), see e.g.: Lithuanian Supreme Court's cases: Norkūnas v Lithuania 302/05 (20 January 2009); S. R. v Lietuvos valstybe 3 K-7-375/2011 (2 December 2011).

95 Case 3 K-3-236/2014 (Lithuanian Supreme Court, 24 April 2014).

96 Case 3 K-3-455/2014 (Lithuanian Supreme Court, 20 October 2014). 
In its judgments, the Lithuanian Supreme Administrative Court formulated the doctrinal principle according to which the conditions of detention cannot constitute a violation of human dignity or fundamental rights that are guaranteed by the Constitution and the ECHR. It is invoked both in resolving administrative disputes concerning the conditions of detention, as well as in matters concerning the legitimacy of imposing disciplinary penalties. ${ }^{97}$ In the context of inhuman or degrading treatment, the Lithuanian Supreme Administrative Court will in addition to the standard contained in the ECHR invoke Article 5 of the Universal Declaration of Human Rights, ${ }^{98}$ Article 7 of the International Covenant on Civil and Political Rights, ${ }^{99}$ the Convention against Torture and other Cruel, Inhuman or Degrading Treatment or Punishment, ${ }^{100}$ and Article 4 of the Charter of Fundamental Rights of the EU.101

The Supreme Court often considered closely the content of Article 7 ECHR with regard to the prohibition of punishment without legal basis ${ }^{102}$ and the principle of the presumption of innocence. The principle of the presumption of innocence has been confirmed not only in domestic law, but also on the international level in Article 6(2) ECHR, which provides that each person accused of a crime is deemed innocent until guilt is proven according to the law. In judicial practice, when interpreting and applying the rules of Article 44(6) of the Code of Criminal Procedure, the ECtHR case law plays an important role in matters concerning Article 6(2) ECHR. The ECtHR in its judgments noted that a breach of the presumption of innocence occurs when the court's decision related to an accused in a criminal matter reflects an opinion on the guilt of the person without proving it according to the law. It is sufficient (even in the absence of any formal request) if the court's deduction indicates that the court considered a suspect guilty. ${ }^{103} \mathrm{Ac}-$ cording to the ECtHR, there should be a clear distinction between a clear statement on the issue of guilt (in the absence of a final judgment) and a statement on the issue of direct suspicion of committing a crime. The first one violates the principle of presumption of innocence, and the second is in accordance with Article 6 ECHR. ${ }^{104}$

97 Lietuvos vyriausiojo administracinio teismo $2014 \mathrm{~m}$. balandžio 9 d. aprobuotas Lietuvos vyriausiojo administracinio teismo praktikos, nagrinejjant bylas dèl bausmių vykdymo ir kardomojo suèmimo institucijų, istaigų ir pareigūnų veiksmų ir sprendimų viešojo administravimo srityje, apibendrinimas", op. cit.

98 Adopted on 10 December 1948 in Paris.

99 Adopted on 16 December 1966 in New York.

100 Adopted on 10 December 1984 in New York.

101 Charter of Fundamental Rights of the EU, 2000/C, 364/01.

102 See e.g. case 2 K-P-93/2014 (Lithuanian Supreme Court, 11 April 2014).

103 ECtHR cases: Minelli v Switzerland, App. no. 8660/79 (25 March 1983); Englert v Germany, App. no. 10282/83 (25 August 1987); Nölkenbockhoff v Germany, App. no. 10300/83 (25 August 1987); Capeau v Belgium, App. no. 42914/98 (13 January 2005).

104 Vulakh and others v Russia, App. no. 33468/03 (ECtHR, 10 January 2012). 
The principle of audi alteram parteman was explained in one of the judgments of the Supreme Court in 2014. In the cassation, the appellant pointed to the right to a fair trial under Article 6(1) ECHR (the need to ensure the principle of audi alteram parteman):

At this point, the importance of the general principles concerning guarantees of the audi alteram parteman made by the ECtHR must be recalled. Provided for by Article 6, the concept of the fairness of the process includes the right of the parties to present evidence of their claims and demands, as well as the right to comment on all the evidence that could affect the outcome (see: Nideröst-Huber $v$ Switzerland, 18 February 1997, Reports 1997-I, p. 108, para. 24; KS v Finland, No. 29346/95, para. 21, 31 May 2001; Duraliyski v Bulgaria, No. 45519/06, 3 March 2014, para. 30). This principle refers to the statements of the parties in the process, government officials (see: Kress $v$ France [GC], No. 39594/98, para. 65, ECtHR $2001 \mathrm{VI}$ ), representatives of the state administration (see: Krčmár and Others $v$ The Czech Republic, No. 35376/97, paras 38-46, 3 March 2000) or the court whose decision is being appealed (see: cited case: Nideröst-Huber $v$ Switzerland). In addition, the ECtHR found that judges should also respect the principle audi alteram parteman [...] (see: Prikyan and Angelova, No. 44624/98, 16 February 2006, para. 42; Clinique des Acacias and Others $v$ France, Nos 65399/01, 65406/01, 65405/01 and 65407/01, para. 38, 13 October 2005; Skondrianos v Greece, Nos 63000/00, 74291/01 and 74292/01, paras 29-30, 18 December 2003 and other). In this context, it is important that the parties of the process trust the justice system: this trust, among other things, is based on the belief that the case in the proceedings will be heard in terms of all its components. In other words - parties to the dispute have a reason to expect that they will be asked to comment on the issue of a particular document or argument (see: mutatis mutandis, Krčmár and Others $v$ The Czech Republic, No. 35376/97, para. 43, 3 March 2000). ${ }^{105}$

In the case of damage caused by the illegal actions of officials, the Supreme Court analysed the international provisions in matters concerning the European Convention on Mutual Assistance in Criminal Matters of 1959, ${ }^{106}$ the European Convention on the Transfer of Proceedings in Criminal Matters of 1972, ${ }^{107}$ and the Convention on Mutual Assistance in Criminal Matters between the Member States of the European Union of $2000,{ }^{108}$ and concluded that

even in special cases where officials of a foreign state within the framework of legal cooperation in a certain field could perform actions on the territory of the Republic of Lithuania, the Lithuanian State is responsible for the damages caused by their actions to Lithuanian entities. ${ }^{109}$

105 Case 3 K-3-363/2014 (Lithuanian Supreme Court, 27 June 2014).

106 Adopted on 20 April 1959 in Strasbourg.

107 Adopted on 15 May 1972 in Strasbourg.

108 Convention on Mutual Assistance in Criminal Matters between the Member States of the European Union, 2000/C, 197/01.

109 Case 3 K-3-634/2013 (Lithuanian Supreme Court, 4 December 2013). 


\subsection{The Protection of Private and Family Life}

Based on the standards for the protection of private and family life (Article 8 ECHR), the Lithuanian Supreme Administrative Court decided, among others, on an applicant's right to give birth at home and to obtain a full necessary assistance:

The applicant requested that the Ministry of Health should ensure her proper care when giving birth at home and should obligate the health care institutions subordinate to the Ministry to provide the applicant with necessary assistance, or that the acts implementing the relevant laws be amended and the appropriate legislation amendments be initiated, so that health care institutions and qualified specialists could provide the applicant with necessary assistance. [...] The violation of Article 8 of the Convention, as found in the judgment of the ECtHR in the case Ternovszky v Hungary and which was pointed to by the applicant, does not, in itself, constitute any ground for holding in the case at issue that there has been a violation of Article 8 of the Convention with regard to the applicant. The aforementioned case was considered by the ECtHR in the context of particular circumstances and within the legal regulation of the state concerned. The interpretation provided in that judgment by the ECtHR, to the effect that the circumstances of giving birth incontestably form part of one's private life, is similarly relevant to the case at issue. However, in the opinion of the panel of judges, under the circumstances of the case at issue, there is no ground for stating that the right of the applicant to the privacy of her personal life has been violated in terms of Article 8 of the Convention. [...] In the case at issue, the applicant has not proved in what way the defendant has violated, or created preconditions for violating, the privacy of her personal life. ${ }^{110}$

In 2015 the Lithuanian Supreme Administrative Court invoked the right to private and family life within the Article 8 ECHR in 10 cases.

\subsection{Freedom of Expression}

In relation to freedom of expression protected by Article 10 ECHR, the Lithuanian Supreme Administrative Court and the Supreme Court in their case law have both shown that in the situation of conflict with the protection of dignity and privacy, the key issue is to balance the conflicting values. In such matters Lithuanian courts have evoked the interpretation to be found in ECtHR case law, especially in the context of the limits of freedom of expression. In the case of the scope of freedom of expression concerning advertisement that violates socially accepted moral principles, the ECtHR has additionally referred to Articles 19 and 20 ICCPR. ${ }^{111}$ In 2015, with reference to treaty standards relating to freedom of ex-

110 Case A-146-24-14 (Lithuanian Supreme Administrative Court, 22 January 2014).

111 Case P-492-119-14 (Lithuanian Supreme Administrative Court, 20 November 2014). 
pression, the Lithuanian Supreme Administrative Court considered five cases, and the Supreme Court six.

As for damages to one's reputation in publications, the Lithuanian Supreme Administrative Court stated that:

The European Court of Human Rights has indicated that the safeguard for freedom of expression is afforded by Article 10 of the Convention with regard to the press on the condition that they provide reliable information in accordance with the ethics of journalism (the judgment of 14 June 2007 in Hachette Filipacchi Associés v France, etc.). [...] in the opinion of the panel of judges, in the case under consideration, the applicant, when publishing the publications in question, failed to comply with the requirements of the Code and, thus, breached the limits of freedom of expression; whereas the limitation on freedom of expression for the purposes of protecting the rights and reputation of a person, as indicated before, is reasonable both in terms of national and international legal norms; therefore, the applicant's freedom of expression was not violated. ${ }^{112}$

\subsection{Rights of a Child}

In matters concerning the protection of children's rights, Lithuanian courts frequently refer to Article $8 \mathrm{ECHR}$ as well as to the provisions of the Convention on the Rights of the Child and the Hague Convention on the Civil Aspects of International Child Abduction.

In the case of international child abductions, the Supreme Court analysed both the right to respect for private life as well as the welfare of the child in the context of the particular circumstances of one case:

[The] ECtHR in its judgments often outlined that national measures that prevent the enjoyment of the right to respect for private life (e.g. the decision to grant custody to one parent) limit the right to respect for private life, which may lead to a breach of Article 8 ECHR, if the restriction is illegal, does not have a legitimate aim within the meaning of Article 8(2) and is not 'necessary in a democratic state' (e.g. Diamanate and Pelliconi $v$ San Marino, App. no. 32250/08, 27 September 2011, paras 171-172). It should be noted that the principle that results from the case law of the ECtHR and Article 8 ECHR is that the state in deciding on the care of the child uses a wide discretion, which becomes narrower when deciding on the contacts of the child with a parent (because there is a risk of interruption of the relationship between parents and a little child), (see: Diamanate and Pelliconi $v$ San Marino, No. 32250/08, 27 September 2011, paras 175 et seq.). In any case, the most important thing in such cases is to assess the welfare of the child. This includes taking into account the views of the child (expressed directly or through the custodian). The case law of the ECtHR emphasizes the importance of the opinion of the child - the older a child is, the more importance is given to his opinion (in Hokkanen $v$ Finland, the Court found that

112 Case A-662-1078-14 (Lithuanian Supreme Administrative Court, 12 May 2014). 
a twelve years old girl is mature enough to take her opinion into consideration). [...] However, the opinion of the child is only one piece of evidence, it is necessary to assess other significant circumstances (e.g. Gineitiene v Lithuania, No. 20739/05, 27 July 2010, para. 38). [...] Other circumstances of the case (taking away a child abroad, proceedings on the return of the child under the Hague Convention) allow the conclusion of the irresponsibility of the mother, her selfishness and disregard concerning the interests of the child (in terms of contacts with both parents). ${ }^{113}$

In assessing the scope of the needs of the child, the Supreme Court in its judgments invoked both the Convention on the Rights of the Child (Articles 3, 27), as well as the provisions of national law (Article 3155 of the Civil Code, Articles 7, $8,11-14,18$ of the Law on the protection of the rights of the child). ${ }^{114}$ The Court widely invoked international standards in cases concerning sexual abuse of children. In 2014 it recalled the Optional Protocol to the Convention on the Rights of the Child on the sale of children, child prostitution and child pornography of 2000, the Recommendation of the Committee of Ministers 2004/68/EC on combating the sexual exploitation of children and child pornography, the Convention of the Council of Europe on the protection of children against sexual exploitation and sexual abuse of 2007, as well as the Directive of the EU Parliament and the EU Council 2011/36/EU on preventing and combating trafficking in human beings and protecting its victims. ${ }^{115}$

Often, international standards and practice of the ECtHR are considered in cases concerning the custody of children, in which Lithuanian courts generally analyse child's welfare, taking into account all the circumstances of the case. ${ }^{116}$

\subsection{The Right to Liberty and Security of a Person}

As for Article 5 ECHR on the right to liberty and security of person, the Lithuanian Supreme Administrative Court and Supreme Court have referred to it frequently in matters concerning the civil liability of the State Treasury for damage caused by the unlawful actions of officers, prosecutors, and judges, as well as in the context of the assessment of the legality of detention. For example, in its judgment of 2014 the Supreme Court declared: "Hearing the case, the court has not sufficiently examined whether during the arrest of the applicant, there was sufficient evidence to suspect she had committed a crime. The Court has not assessed the main circumstances, has not examined the merits of suspicion within

113 Case 3 K-3-455/2014 (Lithuanian Supreme Court, 20 October 2014).

114 See e.g.: case 3 K-3-325/2014 (Lithuanian Supreme Court, 20 June 2014).

115 Lithuanian Supreme Court's cases: 2 K-432/2014 (11 November 2014); 2 K-7-87/2014 (18 February 2014).

116 See: Lithuanian Supreme Court's cases: 2 AT-38-2014 (1 July 2014); 3 K-3-444/2014 (17 October 2014); 3 K-3-454/2014 (24 October 2014); 3 K-3-202/2014 (11 April 2014). 
the meaning of Article 5 para. 1(c) ECHR, and hence the Supreme Court decides to refer the case back to the court of appeal."117

As regards the use of temporary coercive measures, and the right to a hearing within a reasonable time, the Supreme Court stated:

For deprivation of liberty to be in conformity with the requirements of Article 5 para. 1 ECHR, first, it must be 'legal', including in involving a national procedure; in this respect the ECtHR refers to national regulations. In addition, any deprivation of liberty must be justified by the objective of Article 5 ECHR in the protection of the individual against arbitrariness [...] (Liuiza v Lithuania, App. no. 13472/06, judgment of 31 July 2012; Jéčius v Lithuania, No. 34578/97, judgment of 31 July 2000). In addition, the arrested suspect has the right to a hearing as soon as possible (Article 5(3) ECHR). ${ }^{118}$

The Supreme Court also raised this treaty standard in matters relating to the excessive length of pre-trial detention. ${ }^{119}$

\subsection{Freedom of Association}

The Supreme Court in one of its cases concerning the freedom of association issued on the exclusion of an individual from a hunting association:

The right to free association is both constitutional and treaty law. Article 11 ECHR confirms two equivalent rights - the right to free association (not to join an association) and the right of associations to determine their rules of operation, management, internal order, and the freedom in the selection of its members. [...] The case law of the ECtHR explains that Article 11 ECHR cannot be understood as requiring of associations and organizations that they include in their ranks any person who requests so. Where associations are formed of people who, professing the same values and ideals, pursuing common objectives, an inability to control the issue of membership would be a negation of the effectiveness of that freedom (Associated Society of Locomotive Engineers \& Fireman (ASLEF) v United Kingdom, No. 11002/05, judgment of 27 February 2007). When the collision of two conflicting interests - of an association and of its members - takes place, in each case it is important to determine a fair and appropriate balance. The court, in assessing any restrictions on treaty rights, is basing its findings on an analysis of the conditions of legality, proportionality and necessity in a democratic society. The ECtHR noted that although pluralism, tolerance and open-mindedness are a sign of a democratic society, sometimes individual interests must be subordinated to the interests of the group; however democracy does not always mean the primacy of the majority opinion: in each case there should be a balance, ensuring fair and proper treatment of minorities, without any abuse of a dominant position (Associated Society of Locomotive

117 Case 3 K-3-346/2014 (Lithuanian Supreme Court, 27 June 2014).

118 Case 3 K-3-302/2014 (Lithuanian Supreme Court, 6 June 2014).

119 Case 3 K-3-129/2014 (Lithuanian Supreme Court, 10 January 2014). 
Engineers \& Fireman (ASLEF) v United Kingdom, No. 11002/05, judgment of 27 February 2007). ${ }^{120}$

In its judgment of 2010, the Lithuanian Supreme Administrative Court confirmed the right of assembly of sexual minorities, referring to, among others, to the ECtHR judgement of 3 May 2007 in Baczkowski v Poland, which emphasized the importance of pluralism in a democratic society and the need to protect the rights of sexual minorities. ${ }^{121}$

\subsection{Prohibition of Discrimination}

One of the examples of a broader reference to an international standard in the field of non-discrimination is the Supreme Court's judgment of 2014 in a case involving incitement to ethnic hatred:

The college of judges in the application of Article 170 of the Penal Code (incitement to hatred on national, racial, ethnic, religious or any other ground) draws attention to the provisions of the Lithuanian Constitution, as well as the provisions of EU law and international law, which prohibits discrimination against persons or groups of persons on grounds of nationality, race, sex, origin, religion or any other affiliation. The prohibition of discrimination was established in many international and European law instruments. In the context of the case at issue the attention should be paid to the International Convention on the Elimination of All Forms of Racial Discrimination. Article 4 of the Convention indicates that Member States condemn and prevent any propaganda and activities of the organization, which [...] justifies the superiority of one race or nationality over others, in any form of incitement to hatred or racial discrimination. States, taking into account the principles of the Universal Declaration of Human Rights, as well as Article 5 of the mentioned Convention are required to prohibit the incitement to hatred in national law. [...] Based on Article 6 of the Convention, States have an obligation to ensure to everyone an effective legal and judicial protection against any act of racial discrimination, which violates the Convention. [...] Article 20(2) ICCPR prohibits incitement to hatred on national, racial or religious grounds. An important role in clarifying the scope of the prohibition of discrimination and the obligations of States in this respect involves Article 14 ECHR and the practice of the ECtHR. It should be noted that Article 14 cannot be invoked alone, but only in relation to the rights and freedoms of the Convention or additional protocols. [...] The ECtHR has repeatedly stated that any different treatment on grounds of ethnic origin may have an objective justification in a modern democratic society which respects the principles of pluralism and respect for other cultures. Discrimination based on ethnic origin is a form of racial discrimination (Mižigárová $v$ Slovakia, No. 74832/01, judgment of 14 December 2010, para. 114). The case law of the ECtHR

120 Case 3 K-3-485/2014 (Lithuanian Supreme Court, 12 November 2014); see case V. L. v Tauragés medžiotojų klubas Sakalas 3 K-7-470/2009 (Lithuanian Supreme Court, 15 December 2009).

121 Case AS822-339/2010 (Lithuanian Supreme Administrative Court, 10 May 2010). 
stresses that racial discrimination deserves special condemnation because of its dangerous consequences and requires a particular attention and decisive action from the State (Nachova and Others v Bulgaria, Nos 43577/98 and 43579/98, judgment of 6 July 2005, para. 145; Aksu v Turkey, Nos 4149/04 and 41029/04, judgment of 15 March 2012, para. 44). According to the ECtHR's practice, racist ideas which seek to incite hatred or violence, according to Article $17 \mathrm{ECHR}$ (prohibition of abuse of rights) in particular do not enjoy protection under Article 10 ECHR (freedom of expression) (e.g. Molnar c. Roumanie, No. 16637/06, décision du 23 octobre 2012; Ivanov v Russia, No. 35222/04, decision of 20 February 2007). [...] According to the case law of the ECtHR in cases of infringement of Article 2 ECHR (right to life), Article 3 ECHR (prohibition of torture) and Article 14 ECHR, state institutions which investigate these matters are required to clarify whether they have been committed because of racial hatred, or whether such beliefs influenced the incident (e.g. Abdu c. Bulgarie, No. 26827/08, arrêt du 11 mars 2014; Yotov c. Bulgarie, No. 43606/04, arrêt du 23 octobre 2012; Beganović v Croatia, No. 46423/06, judgment of 25 June 2009; Angelova and Iliev v Bulgaria, No. 55523/00, judgment of 26 July 2007; Šečić v Croatia, No. 40116/02, judgment of 31 May 2007; Nachova and Others $v$ Bulgaria). [...] The identity of ethnic groups in the jurisprudence ECtHR is treated as an essential aspect of identity and private life (Ciubotaru $v$ Moldova, App. no. 27138/04, judgment of 27 April 2010, paras 49, 153). ${ }^{122}$

However, Lithuanian courts have not always interpreted the international principle of non-discrimination properly. For example, the 2013 decision of the Lithuanian Supreme Administrative Court on the unification of the Lithuanian language exam for schools with Lithuanian language of instruction and national minority schools, without an adequate transitional period, shows shortcomings in this respect. In its justification, the Lithuanian Supreme Administrative Court, quoting the provisions of the Framework Convention for the Protection of National Minorities ${ }^{123}$ and the OSCE Hague Recommendations on educational rights of national minorities ${ }^{124}$ did not find a breach of the principle of non-discrimination in relation to pupils from non-Lithuanian schools. Moreover, the Court declared that measures to assist minority pupils in their assessments during exams to be unconstitutional because they were contrary to the principle of equality. ${ }^{125}$ It seems that for the Court in this case, positive measures aimed at achieving substantive equality were paramount to an act of discrimination. ${ }^{126}$ Such an

122 Case 2 K-359/2014 (Lithuanian Supreme Court, 14 October 2014).

123 Adopted on 1 February 1995 in Strasbourg.

124 Adopted in October 1996 in the Hague.

125 Pupils from minority schools had to catch up the difference of 818 hours of Lithuanian language lessons (compared to pupils from schools with Lithuanian language of instruction) within 2 years since the introduction of the amendments of Law on Education in 2011. First unified exam was held in 2013. The Ministry of Education and Science of Lithuania introduced evaluative facilitations for students of non-Lithuanian language schools in order to partially compensate the unequal opportunities during the exam. LNSA in its judgment considered these facilitations to be contrary to the constitutional principle of equality.

126 Case I261-16/2013 (Lithuanian Supreme Administrative Court, 18 June 2013). 
approach seems to ignore, and to violate, the basic premises in the international protection of the rights of national minorities, which are based on the principle of non-discrimination and the protection of the identity and special characteristics of minorities. The Advisory Committee of the Council of Europe, which regularly assesses the application of the provisions of the Framework Convention in Lithuania, pointed to the defects in Court's reasoning. ${ }^{127}$ However, the reference made by the Court to soft law (the Hague Recommendations) - despite the misinterpretation of their provisions - should be considered as a positive development.

\section{The Challenges for the Judicial Dialogue in Lithuania}

The harmonization of national law with Lithuania's international obligations and their practical application is an on-going process. Essentially, three centres control this process: the Constitutional Court, the Supreme Court and the Lithuanian Supreme Administrative Court. Their decisions and judgments are binding for all common courts in Lithuania and together constitute an indication as to the uniform practice for the application of national law in the context of international standards. The publication of an overview of international and foreign laws and practices both in the Lithuanian Supreme Administrative Court Bulletin and the Supreme Court's bulletin entitled Judicial practice makes it easier for common courts to invoke and discuss international and European standards. Certainly, one of the most effective ways of making Lithuanian judges familiar with supranational and international law (although requiring significant time and efforts) are conferences and seminars as well as study visits to Luxembourg and Strasbourg. We must express the hope that the percentage of Lithuanian decisions consistent with European standards will grow.

At this point two basic challenges for judicial dialogue in Lithuania should be highlighted. Firstly, further efforts concerning bringing domestic legislation and interpretation in line with supranational and international law and jurisprudence must be undertaken. Secondly, domestic courts must develop a much deeper appreciation of the principles, standards and values of international law, the principles of customary law, and the concepts of international legal protection, including soft law.

127 Third Opinion on Lithuania adopted on 28 November 2013, Advisory Committee on the Framework Convention for the Protection of National Minorities, ACFC/OP/III(2013)005 (Strasburg, 10 October 2014), para. 87. 
The context of the first mentioned challenge relates basically to a wider consideration of the case law (and applicable standards) of the Strasbourg and Luxembourg courts in the practice of Lithuanian courts. As an illustrative example, one can specify the application of Article 1 of the Protocol 1 to the ECHR (on the protection of property), particularly with regard to the restitution of nationalized property during the Soviet era. It should be mentioned that currently the vast majority of the complaints against Lithuania before the ECtHR contain allegations of infringement of the right to property. One such case under examination before the Strasbourg Court is Monika Korkuć and Others v Lithuania (App. no. 21920/10). It will be a critical judgement, potentially defining the responsibilities of States in the restitution of property taken over by communist regimes. ${ }^{128}$

As for the second challenge, the need for a more comprehensive understanding of the international standards' system must be highlighted. Declarations and non-binding international legal instruments (soft law) may be used in order to clarify existing standards and used in the legal reasoning adopted in judgments. Lithuanian courts appear sometimes to be lacking an in-depth analysis and reflection on the subject of the values protected by a given international agreement. For example, the protection of national minorities, expressed mainly in the Framework Convention for the Protection of National Minorities (not of a strict hard law nature, and even less in domestic law, because of its framework nature), still has not found its rightful place in the judgments of Lithuanian courts. The Lithuanian analysis of the standards contained in this treaty remains limited to stating the primacy of the constitutional principle of equality over the provisions aimed at achieving substantive equality between minorities and majorities. Courts in Lithuania should pay more attention to the rules of interpretation and the recommendations formulated by the Advisory Committee and the Committee of Ministers with regard to this treaty, expressed in the observations of these two bodies on the rights of national minorities in Lithuania following the monitoring cycle once every four years.

128 Brief statement of facts and legal issues involved: Regulation of the Government of Lithuania in 2002 expanded the concept of 'forests of national importance'. This has changed the mode of restitution of nationalized land - it banned the return of forested in the territories enclosed to Vilnius after 1995. According to the law forests in cities may belong only to the state/local government (protection of the public interest). Consequently, on the basis of proposals from the district prosecutor's offices, series of decisions on the restitution to the rightful owners of the nationalized land property adopted in 2001-2006 by the local administration have been canceled (more than 150 decisions). This invalidated the entire decision on restitution, not just a part concerning forested areas.

According to the applicants, the decision granting them the right to property were annulled without any compensation. Government of Lithuania argued that the applicants despite the annulled decisions, still retain the right to regain the nationalized property (according to the legislation it is possible to regain the land in other than the nationalized property place). The problem, however, lies in the fact that there is less and less grounds that could be returned and some plots are located in unattractive locations. 


\section{Conclusions}

The practice of Lithuanian courts of recalling and referring to the standards and jurisprudence of international law in slightly more than twenty years must be assessed positively. The judicial dialogue in Lithuania has a clear legal basis, especially in the context of the constitutional obligations to respect and apply international law. Lithuania's membership in all major European and international organizations has transformed Lithuanian legal area into a space of international standards.

Firstly, it should be noted in general, that international standards and international court judgments affect the Lithuanian judicature, Lithuanian law and its interpretation. EU law and Strasbourg standards have a special place in the judgments of Lithuanian courts. This is mainly due to the binding nature of the decisions of the courts in Luxembourg and Strasbourg. The judgments of the courts and tribunals of foreign countries do not have a direct role in the Lithuanian courts' grounds for judgments at the moment (even as an additional argument). There is also no widespread practice of relying on the international principles of customary law.

Secondly, Lithuanian courts, despite a relatively brief tradition of invoking international regulations and rulings, increasingly apply supranational and international law. The Supreme Court itself deviates from the practice of general noting the existence of an international standard and has adopted a broader and a deeper analysis of international law. A special place and a role of the principles of non-discrimination and proportionality should be noted, which, due to the jurisprudence of CJEU, has also reached Lithuanian case law.

Thirdly, international law is applicable both as a backup for the interpretation of national law, as well as a self-sustaining basis for adjudication. Examples of direct application of international standards are particularly visible in cases where the relevant national legislation was or has been missing. ${ }^{29}$

There is a tendency in Lithuania to conclude that a violation of ECHR or EU law also violates a constitutional standard. It seems that this approach plays two roles: first, it indicates that the European standard is applied; secondly, it implies the compliance of the provisions of the Constitution with an international standard (especially in the light of the principle of the primacy of the Constitution in the national law system). In this context, the importance of the role of the Strasbourg

129 Till 2010 Lithuanian Supreme Administrative Court when deciding was referring to the Aarhus Convention on access to information, participation in decision-making and access to justice in matters of environmental protection directly, as by that time there was no appropriate national legislation in this regard. A similar situation concerned European norms and standards in the field of intellectual property protection. 
and Luxemburg standards as rules for the interpretation of the provisions of the Constitution must be noted. ${ }^{130}$

It is also important that the Lithuanian Supreme Administrative Court and the Supreme Court invoke international standards and interpretations in order to maintain a uniform practice of their application in the domestic law system. At the same time, courts retain the interpretation presented by the international judicial bodies, without trying to challenge it against the interests of the state. In most cases the Lithuanian Supreme Administrative Court quotes external decisions in order to support its reasoning as well as to maintain a uniform approach consistent with an international law legal practice, especially in the context of European and Convention standards. In Lithuanian case law there is no tradition of invoking external decisions in order to criticize them or to engage in polemics.

Finally, it is impossible not to note the role of parties in proceedings (and their representatives) in the judicial dialogue in Lithuania. In order to support their arguments, they often raise both the EU and Convention standards, in a way forcing a national court to analyse international provisions in the matters under consideration.

130 For example: Supreme Court's judgments of 22 December 2011, 21 December 2006, 15 May 2007, 27 February 2012. 


\section{Bibliography}

\section{Case Law}

\section{ECtHR}

Minelli v Switzerland, App. no. 8660/79 (25 March 1983)

Englert v Germany, App. no. 10282/83 (25 August 1987)

Nölkenbockhoffv Germany, App. no. 10300/83 (25 August 1987)

Capeau v Belgium, App. no. 42914/98 (13 January 2005)

Norkūnas v Lithuania, App. no. 302/05 (20 January 2009)

Cudak v Lithuania, App. no. 15869/02 (23 March 2010)

Vulakh and others v Russia, App. no. 33468/03 (10 January 2012)

\section{Lithuanian Constitutional Court}

Conclusions (24 January 1995)

Judgement (17 October 1995)

Judgment (8 May 2000)

Judgment (14 March 2006)

Judgment (14 March 2006)

Judgment (21 December 2006)

Judgment (5 September 2012)

\section{Lithuanian Supreme Court}

3 K-53/1998 (14 September 1998)

3 K-3-25/2000 (25 January 2000)

3 K-3-554/2000 (17 May 2000)

3 K-3-927/2001 (1 January 2001)

$3 \mathrm{~K}-3-875 / 2001$ (1 October 2001)

3 K-3-167/2003 (7 January 2003)

3 K-3-375/2003 (26 March 2003)

3 K-3-1103/2003 (15 December 2003)

3 K-3-301 (12 December 2004)

3 K-3-135 (21 March 2005)

3 K-3-150 (23 March 2005)

3 K-3-170 (6 March 2006)

3 K-3-202 (22 March 2006)

3 K-3-209 (27 March 2006)

3 K-3-669 (20 December 2006)

3 K-3-690/2006 (29 December 2006)

3 K-3-690 (29 December 2006)

3 K-3-91/2008 (7 January 2008) 
3 K-7-470/2009 (15 December 2009)

3 K-7-375/2011 (2 December 2011)

3 K-3-207/2012 (14 May 2012)

3 K-7-326/2013 (10 October 2013)

3 K-3-634/2013 (4 December 2013)

2 K-111/2014 (7 January 2014)

3 K-3-129/2014 (10 January 2014)

2 K-P-1/2014 (30 January 2014)

2 K-7-87/2014 (18 February 2014)

2 K-P-93/2014 (11 April 2014)

3 K-3-202/2014 (11 April 2014)

3 K-3-199/2014 (11 April 2014)

3 K-3-219/2014 (16 April 2014)

3 K-3-236/2014 (24 April 2014)

3 K-3-302/2014 (6 June 2014)

3 K-3-302/2014 (6 June 2014)

$3 \mathrm{~K}-3-322 / 2014$ (13 June 2014)

$3 \mathrm{~K}-3-357 / 2014$ (20 June 2014)

$3 \mathrm{~K}-3-324 / 2014$ (20 June 2014)

3 K-3-325/2014 (20 June 2014)

3 K-3-324/2014 (20 June 2014)

3 K-3-357/2014 (20 June 2014)

3 K-3-363/2014 (27 June 2014)

$3 \mathrm{~K}-3-346 / 2014$ (27 June 2014)

3 K-3-363/2014 (27 June 2014)

2 AT-38-2014 (1 July 2014)

2 K-359/2014 (14 October 2014)

3 K-3-444/2014 (17 October 2014)

3 K-3-455/2014 (20 October 2014)

$3 \mathrm{~K}-3-455 / 2014$ (20 October 2014)

2 K-425/2014 (21 October 2014)

3 K-3-454/2014 (24 October 2014)

2 K-368/2014 (4 November 2014)

2 K-432/2014 (11 November 2014)

3 K-3-485/2014 (12 November 2014)

e3 K-3-406-378/2015 (26 June 2015)

3 K-3-477-684/2015 (18 September 2015)

2 K-388-507/2015 (22 September 2015)

3 K-3-593-687/2015 (6 November 2015)

3 K-3-685-219/2015 (23 December 2015)

3 K-3-4-378/2016 (3 February 2016) 


\section{Lithuanian Supreme Administrative Court}

A7-335/2003 (24 June 2003)

A575-164/2008 (14 April 2008)

575-1387-09 (28 December 2009)

AS822-339/2010 (10 May 2010)

A858-1452/2010 (29 November 2010)

A438-2713/2011 (28 November 2011)

AS146-380/2012 (13 July 2012)

A444-2727/2012 (9 August 2012)

A520-2823/2012 (17 September 2012)

I261-16/2013 (18 June 2013)

A520-211/2013 (23 September 2013)

A-146-24-14 (22 January 2014)

A-146-95-14 (10 February 2014)

R-525-8-14 (6 March 2014)

A-146-342-14 (10 April 2014)

P-492-71-14 (30 April 2014)

P-492-71-14 (30 April 2014)

A-662-1078-14 (12 May 2014)

A-662-1579-14 (19 May 2014)

P-756-46-14 (28 May 2014)

A-442-707-14 (9 October 2014)

A-556-1535-14 (28 October 2014)

P-492-119-14 (20 November 2014)

\section{Vilnius Court of Appeal}

2-1212-553/2011 (11 November 2011)

\section{Vilnius district court}

2-1212-553/2011 (13 May 2011)

\section{References}

Apolevič J., Leonaitè E., Republic of Lithuania Materials on International Law 2014 (Brill Nijhoff, Boston 2016)

Civil Proceedings Code (Lietuvos Respublikos civilinio proceso kodeksas, No. 36-1340, 2002)

The Constitutional act on membership of the Republic of Lithuania in the European Union (Lietuvos Respublikos Seimas Istatymas IX-2343 (Žin., 2004-07-13); Lietuvos Respublikos Konstitucijos papildymo Konstituciniu aktu "Dèl Lietuvos Respublikos narystes Europos Sajungoje" ir Lietuvos Respublikos Konstitucijos 150 straipsnio papildymo įstatymas) 
European Council Regulation (EC) No. 1383/2003 of 22 July 2003 concerning customs action against goods suspected of infringing certain intellectual property rights and the measures to be taken against goods found to have infringed such rights

Law on Administrative Proceedings (Lietuvos Respublikos administraciniu bylu teisenos istatymas, No. VIII-1029, 14 January 1999)

Law on Civil Proceedings IX-743 (Lietuvos Respublikos civilinio proceso kodekso patvirtinimo, įsigaliojimo ir igyvendinimo istatymas, 28 February 2002)

Law on International Treaties (Lietuvos Respublikos Tarptautiniu sutarčiu įstatymas, No. VIII-1248, 22 June 1999)

'Lietuvos vyriausiojo administracinio teismo 2014 m. balandžio 9 d. aprobuotas Lietuvos vyriausiojo administracinio teismo praktikos, nagrinejant bylas dèl bausmių vykdymo ir kardomojo suėmimo institucijų, Ł̇staigų ir pareigūnų veiksmų ir sprendimų viešojo administravimo srityje, apibendrinimas', Administraciné jurisprudencija (2014) 26

Special statement of the Lithuanian Constitutional Court (Lietuvos Respublikos Konstitucinio Teismo specialusis pareiškimas "Dèl Europos Žmogaus teisių teismo 2001 m. sausio 6 d. sprendimo igyvendinimo", 10 January 2011)

Strazdaite E., Europos Sajungos teises taikymas Lietuvos Respublikos teismuose (Vilniaus universitetas 2007)

Transparency International Lietuvos skyrius, 'Statistics', <http://atvirasteismas.lt/> (access: 10 October 2016)

Third Opinion on Lithuania adopted on 28 November 2013, Advisory Committee on the Framework Convention for the Protection of National Minorities, ACFC/OP/III(2013)005 (Strasburg, 10 October 2014)

\section{Other}

Charter of Fundamental Rights of the European Union (2000/C, 364/01)

Convention against Torture and other Cruel, Inhuman or Degrading Treatment or Punishment, adopted on 10 December 1984 in New York

Convention on Access to Information, Public Participation in Decision-making and Access to Justice in Environmental Matters, adopted on 25 June 1998 in Aarhus

Convention on Mutual Assistance in Criminal Matters between the Member States of the European Union (2000/C, 197/01)

Convention on the Control and Marking of Articles of Precious Metals

Convention on the Control and Marking of Articles of Precious Metals, adopted on 15 November 1972 in Vienna

Convention on the Elimination of All Forms of Discrimination against Women, adopted on 18 December 1979 in New York

Convention on the Recognition and Enforcement of Foreign Arbitral Awards, adopted on 10 June 1958 in New York

Convention on the Rights of Persons with Disabilities, adopted on 13 December 2006 in New York 
Convention on the Rights of the Child, adopted by General Assembly resolution 44/25 of 20 November 1989

Convention relating to the Status of Refugees, adopted on 28 July 1951 in Geneva

Council of Europe's Convention on the Protection of Children against Sexual Exploitation and Sexual Abuse, adopted on 25 October 2007 in Lanzarote

Council of Europe's Criminal Law Convention on Corruption, adopted on 27 January 1999 in Strasbourg

European Convention on Human Rights as amended by Protocols Nos 11 and 14, supplemented by Protocols Nos 1, 4, 6, 7, 12 and 13, adopted on 4 November 1950 in Rome

European Convention on Mutual Assistance in Criminal Matters, adopted on 20 April 1959 in Strasbourg

European Convention on State Immunity, adopted on 16 May 1972 in Basel

European Convention on the Legal Status of Children Born out of Wedlock, adopted on 15 October 1975 in Strasbourg

European Convention on the Transfer of Proceedings in Criminal Matters, adopted on 15 May 1972 in Strasbourg

European Convention on the Transfer of Sentenced Persons of 1983, adopted on 21 March 1983 in Strasbourg

Framework Convention for the Protection of National Minorities, adopted on 1 February 1995 in Strasbourg

The Geneva Convention on the Contract for the International Carriage of Goods by Road, adopted on 19 May 1956 in Geneva

The Hague Convention on the Civil Aspects of International Child Abduction, adopted on 25 October 1980 in the Hague

The Hague Convention on the Law Applicable to Traffic Accidents, adopted on 4 May 1971 in the Hague

International Covenant on Civil and Political Rights, adopted on 16 December 1966 in New York

OSCE Hague Recommendations on educational rights of national minorities, adopted in October 1996 in the Hague

The Protocol to the Madrid Convention on Registration of Marks International, adopted on 27 June 1989 in Madrid

The Single Convention on Narcotic Drugs, adopted on 30 March 1961 in New York

Treaty between Lithuania and Germany on cooperation in cultural field, (Lietuvos Respublikos Vyriausybès ir Vokietijos Federacinès Respublikos Vyriausybès sutartis dèl bendradarbiavimo kultūros srityje, 21 July 1993)

UN Convention on Jurisdictional Immunities of States and Their Property, adopted on 2 December 2004 in New York

Universal Declaration of Human Rights, adopted on 10 December 1948 in Paris 